\title{
A multimodel assessment of the influence of regional anthropogenic emission reductions on aerosol direct radiative forcing and the role of intercontinental transport
}

\author{
Hongbin Yu, ${ }^{1,2}$ Mian Chin, ${ }^{2}$ J. Jason West,${ }^{3}$ Cynthia S. Atherton, ${ }^{4}$ Nicolas Bellouin, ${ }^{5}$ \\ Dan Bergmann, ${ }^{6}$ Isabelle Bey, ${ }^{7}$ Huisheng Bian, ${ }^{2,8}$ Thomas Diehl, ${ }^{2,9}$ Gerd Forberth, ${ }^{5}$ \\ Peter Hess, ${ }^{10}$ Michael Schulz, ${ }^{11}$ Drew Shindell, ${ }^{12}$ Toshihiko Takemura, ${ }^{13}$ and Qian Tan ${ }^{2,9}$ \\ Received 22 May 2012; revised 19 November 2012; accepted 25 November 2012; published 25 January 2013.
}

[1] In this study, we assess changes of aerosol optical depth (AOD) and direct radiative forcing (DRF) in response to the reduction of anthropogenic emissions in four major pollution regions in the Northern Hemisphere by using results from nine global models in the framework of the Hemispheric Transport of Air Pollution (HTAP). DRF at top of atmosphere (TOA) and surface is estimated based on AOD results from the HTAP models and AOD-normalized DRF (NDRF) from a chemical transport model. The multimodel results show that, on average, a 20\% reduction of anthropogenic emissions in North America, Europe, East Asia, and South Asia lowers the global mean AOD (all-sky TOA DRF) by $9.2 \%(9.0 \%), 3.5 \%(3.0 \%)$, and $9.4 \%(10.0 \%)$ for sulfate, particulate organic matter (POM), and black carbon (BC), respectively. Global annual average TOA all-sky forcing efficiency relative to particle or gaseous precursor emissions from the four regions (expressed as multimodel mean \pm one standard deviation) is $-3.5 \pm 0.8,-4.0 \pm 1.7$, and $29.5 \pm 18.1 \mathrm{~mW} \mathrm{~m}^{-2}$ per Tg for sulfate (relative to $\mathrm{SO}_{2}$ ), $\mathrm{POM}$, and $\mathrm{BC}$, respectively. The impacts of the regional emission reductions on AOD and DRF extend well beyond the source regions because of intercontinental transport (ICT). On an annual basis, ICT accounts for $11 \pm 5 \%$ to $31 \pm 9 \%$ of AOD and DRF in a receptor region at continental or subcontinental scale, with domestic emissions accounting for the remainder, depending on regions and species. For sulfate AOD, the largest ICT contribution of $31 \pm 9 \%$ occurs in South Asia, which is dominated by the emissions from Europe. For BC AOD, the largest ICT contribution of $28 \pm 18 \%$ occurs in North America, which is dominated by the emissions from East Asia. The large spreads among models highlight the need to improve aerosol processes in models, and evaluate and constrain models with observations.

Citation: Yu, H., et al. (2013), A multimodel assessment of the influence of regional anthropogenic emission reductions on aerosol direct radiative forcing and the role of intercontinental transport, J. Geophys. Res. Atmos., 118, 700-720, doi:10.1029/2012JD018148.

\footnotetext{
All supporting information may be found in the online version of this article.

${ }^{1}$ Earth System Science Interdisciplinary Center, University of Maryland, College Park, Maryland, USA.

${ }^{2}$ Earth Science Directorate, National Aeronautics and Space Administration Goddard Space Flight Center, Greenbelt, Maryland, USA.

${ }^{3}$ Department of Environmental Sciences and Engineering, University of North Carolina, Chapel Hill, North Carolina, USA.

${ }^{4}$ Gordon and Betty Moore Foundation, Palo Alto, California, USA.

${ }^{5}$ Met Office Hadley Centre, Exeter, Devon, UK.

${ }^{6}$ Atmospheric Earth and Energy Division, Lawrence Livermore National Laboratory, Livermore, California, USA.

${ }^{7}$ Center for Climate Systems Modeling, Eidgenössische Technische Hochschule (ETH) Zurich, Zürich, Switzerland.

${ }^{8}$ Joint Center for Earth Systems Technology, University of Maryland at Baltimore County, Baltimore, Maryland, USA.

${ }^{9}$ Universities Space Research Association, Columbia, Maryland, USA.

${ }^{10}$ Biological and Environmental Engineering, Cornell University, Ithaca, New York, USA.

${ }^{11}$ Meteorologisk Institutt, Oslo, Norway.

${ }^{12}$ National Aeronautics and Space Administration Goddard Institute for Space Studies, New York, New York, USA.

${ }^{13}$ Research Institute for Applied Mechanics, Kyushu University, Fukuoka, Japan.

Corresponding author: H. Yu, NASA GSFC Code 613, Greenbelt, MD 20771, USA. (hongbin.yu@nasa.gov)
} 


\section{Introduction}

[2] Anthropogenic aerosols make significant contributions to the global mean radiative forcing $(\mathrm{RF})$ of climate [Forster et al., 2007] by scattering and absorbing solar radiation (socalled aerosol direct effects) [McCormick and Ludwig, 1967] and modifying cloud properties, amount, and evolution (collectively referred to as "aerosol indirect effects") [Twomey, 1977; Gunn and Philips, 1957; Albrecht, 1989]. $\mathrm{RF}$ is a measure of the change of net radiation (incoming minus outgoing) at the top of atmosphere (TOA), at the surface, or within the atmosphere, due to perturbations in atmospheric compositions or surface properties. On a global average basis, the sum of direct and indirect RF at TOA by anthropogenic aerosol is estimated to be $-1.2 \mathrm{Wm}^{-2}$ $\left[-2.4\right.$ to $\left.-0.6 \mathrm{~W} \mathrm{~m}^{-2}\right]$ (cooling) over the period of 1750 to 2000, which is significant compared to the positive (warming) forcing of $+2.63[ \pm 0.26] \mathrm{W} \mathrm{m}^{-2}$ by anthropogenic long-lived greenhouse gases over the same period [Forster et al., 2007]. In heavily polluted regions, aerosol cooling overwhelms greenhouse warming [Ramanathan et al., 2001; Li et al., 2010]. At the surface, aerosol RF can be much stronger than that at TOA because of aerosol absorption [Satheesh and Ramanathan, 2000]. Currently, uncertainties associated with aerosol RF make the largest contribution to the overall uncertainty in anthropogenic RF of climate [Forster et al., 2007]. Because of the significant role of aerosols in modulating Earth's radiative budget, it is necessary from both scientific and policy perspectives to assess how emission changes associated with economic development and regional/national regulations will influence the aerosol RF.

[3] The response of global aerosol RF to a change of anthropogenic emissions would depend on the source locations, magnitude, and composition of emitted aerosols and aerosol precursors [Bauer and Menon, 2012; Henze et al., 2012]. Whereas scattering aerosols like sulfate cause a cooling effect, strongly absorbing black carbon (BC) aerosols cause warming. Aerosol RF is also determined by several environmental factors such as surface albedo and meteorological conditions (in particular, the amount and distribution of clouds and winds). It is also important to note that the impact of a regional emission reduction is not necessarily confined to the region itself. Instead, regional emission reductions can have far-reaching impacts on RF in downwind regions, because of intercontinental transport (ICT) of anthropogenic aerosols. Long-range transport has been observed by long-term surface monitoring networks [Prospero et al., 2003; VanCuren, 2003; Fischer et al., 2010], in situ measurements from intensive field campaigns [Ramanathan et al., 2007; Clarke and Kapustin, 2010], and satellite observations [Yu et al., 2008; Rudich et al., 2008; Dirksen et al., 2009; Yu et al., 2012a] backed by model simulations [Heald et al., 2006; Chin et al., 2007; Hadley et al., 2007]. For example, it is estimated from satellite measurements that the aerosol mass flux, including both dust and nondust, via ICT into North America is comparable with the domestic emissions [Yu et al., 2012a]. Thus, how a region is influenced by extraregional emissions could be of particular importance for formulating an effective strategy for mitigating regional climate change and combating air pollution.

[4] Modeling studies can offer valuable insights into the relative significance of aerosols from different regions in influencing climate and the important implications for formulating effective emission-control strategies. Several recent studies have assessed how aerosols emitted in a region or from specific sectors could affect climate in downwind regions [e.g., Reddy and Boucher, 2007; Koch et al., 2007; Shindell et al., 2008a, 2008b; Bauer and Menon, 2012; Henze et al., 2012]. Other studies have shown that large intermodel differences exist in the aerosol life cycle and radiative effect [Kinne et al., 2006; Schulz et al., 2006; Textor et al., 2006], which might undermine the robustness of the results from a single model or very limited number of models.

[5] Under the auspices of the United Nations Economic Commission for Europe (UNECE) Convention on LongRange Transboundary Air Pollution (LRTAP Convention), a Task Force on Hemispheric Transport of Air Pollution (HTAP) was established in 2005 to understand the growing body of scientific evidence of ICT and assess its impacts on air quality, climate, and ecosystems (http:/www.htap.org/). The Task Force on HTAP has organized a comprehensive international assessment activity of the ICT of air pollution in the Northern Hemisphere that involved multiple modeling studies on source attribution and source-receptor $(\mathrm{S} / \mathrm{R})$ relationships [Hemispheric Transport of Air Pollution (HTAP), 2010]. Shindell et al. (2008c) examine the response of Arctic gas and aerosol concentrations to perturbations in pollutant emissions from Europe, East and South Asia, and North America using results from the HTAP experiments.

[6] Complementary to the prior studies, we use in this study an ensemble of nine global chemical transport or general circulation models that participated in the HTAP studies to assess the change of global and regional aerosol optical depth (AOD) and direct radiative forcing (DRF) in response to $20 \%$ reductions of emissions from four major polluted regions in the Northern Hemisphere. These multimodel $\mathrm{S} / \mathrm{R}$ experiments allow us to examine a probable range of contributions of ICT relative to intraregional emissions in determining regional AOD and DRF, and help to characterize the robustness of the results. Fry et al. [2012] conduct similar analysis of ozone RF due to $20 \%$ reductions of ozone precursor emissions using results from multiple HTAP models.

[7] We emphasize the effects of emissions from individual continents on global mean aerosol DRF. In addition, we also present the spatial distributions of the DRF and analyze the effect of ICT by which emissions from one continent influence DRF over another. These spatial patterns of aerosol RF may affect regional climate responses. Several studies have examined relationships between the spatial patterns of RF and climate response. In some cases, the surface temperature responses follow the forcing fairly closely [e.g., Leibensperger et al., 2012b], whereas in others, the location of response is quite different from the location of forcing [e.g., Levy et al., 2008]. The only multimodel intercomparison to date found that although the impact of forcing on surface temperature was generally strong at short distances, the response showed fairly high spatial correlation out to about $3500 \mathrm{~km}$ in the meridional direction (30 degrees) and out to at least $12,000 \mathrm{~km}$ in the zonal direction [Shindell et al., 2010]. Other aspects of climate response such as precipitation appear to be more strongly influenced by local forcing, although again remote forcing can also play a role via induced changes in circulation [Shindell et al., 2012; Bollasina et al., 2011]. Although the climate 
Table 1. List of Nine Models That Participated in Hemispheric Transport of Air Pollution Aerosol Source-Receptor Experiments and Are Used in This Analysis ${ }^{\mathrm{a}}$

\begin{tabular}{lllcl}
\hline Model $^{\mathrm{b}}$ & Model Version & \multicolumn{1}{c}{ Investigator(s) } & Resolution (longitude $\times$ latitude) \\
\hline CAM-CHEM & v3514 & P. Hess & $2.5^{\circ} \times 1.875^{\circ}$ & Pfister et al., 2008; Emmons et al., 2010 \\
ECHAM5 HAMMOZ & v21 & I. Bey, G. Forberth & $2.813^{\circ} \times 2.813^{\circ}$ & Pozzoli et al., 2008a, 2008b \\
GISS PUCCINI & modelEaer & D. Shindell & $5^{\circ} \times 4^{\circ}$ & Koch et al., 2005; Shindell et al., 2006 \\
GMI & v02a & H. Bian & $2.5^{\circ} \times 2^{\circ}$ & Bian et al., 2009 \\
GOCART & v4p2 & M. Chin, T. Diehl & $2.5^{\circ} \times 2^{\circ}$ & Chin et al., 2002, 2007, 2009 \\
HadGEM2 & A-v01 & N. Bellouin & $1.875^{\circ} \times 1.25^{\circ}$ & Bellouin et al., 2011 \\
INCA & v2 & M. Schulz & $3.75^{\circ} \times 2.5^{\circ}$ & Hauglustaine et al., 2004; Textor et al., 2006 \\
LLNL IMPACT & T5a & D. Bergmann, C. S. Atherton & $2.5^{\circ} \times 2^{\circ}$ & Rotman et al., 2004 \\
SPRINTARS & v356 & T. Takemura & $1.125^{\circ} \times 1.125^{\circ}$ & Takemura et al., 2005 \\
\hline
\end{tabular}

${ }^{a}$ Major model characteristics are listed in Table S1 of the supporting information.

${ }^{\mathrm{b}}$ CAM-CHEM, Community Atmospheric Model-Chemistry version (NCAR, Boulder, Colorado, USA); ECHAM5-HAMMOZ, Max-Planck Institute for Meteorology Hamburg Climate Model, version 5 with Hamburg Aerosol Model and MOZART chemistry sub-Module; GISS PUCCINI, Goddard Institute for Space Studies, Physical Understanding of Composition-Climate Interactions and Impacts model (National Aeronautics and Space Administration (NASA) GISS, New York, New York, USA); GMI, Global Modeling Initiative (NASA Goddard Space Flight Center (GSFC), Greenbelt, Maryland, USA); GOCART, Goddard Chemistry Aerosol Radiation and Transport (NASA GSFC, Greenbelt, Maryland, USA); HadGEM2, Hadley Centre Global Environment Model version 2 (Met Office, Devon, U.K.); INCA, Interaction of Chemistry and Aerosol (laboratoire des Sciences du Climat et de l'Environnement, Orme des Merisiers, France); LLNL IMPACT, Integrated Massively Parallel Atmospheric Chemical Transport model (Lawrence Livermore National Laboratory, Livermore, California, USA); SPRINTARS, Spectral Radiation-Transport Model for Aerosol Species (Kyushu University, Fukuoka, Japan).

response is not determined solely by the spatial distribution of aerosol RF, it is important to know the location of aerosol RF and the role of ICT in modulating the spatial patterns of forcing.

[8] The rest of this paper is organized as follows: Section 2 describes the $\mathrm{S} / \mathrm{R}$ model simulations and analysis methodology, including AOD from the HTAP anthropogenic S/R experiment used in this study, an estimate of the aerosol DRF, and a metric that measures the importance of ICT relative to domestic emissions. Section 3 presents results of the baseline simulations of AOD and DRF, the impacts of $20 \%$ reductions of regional anthropogenic emissions on global and regional AOD and DRF, and the role of ICT relative to intraregional emissions based on a multimodel analysis. This assessment does not address aerosol indirect effects or warming effects resulting from $\mathrm{BC}$ deposition on snow and ice. We also neglect interactions of aerosols with thermal infrared radiation, as anthropogenic aerosols have relatively small size and their interactions with infrared radiation are minor. Finally, we neglect the RF of gas-phase components that may have been influenced by these emissions, which were modeled by Fry et al. (2012). Major conclusions from the analysis are summarized and discussed in Section 4.

\section{Description of Model Simulations and Analysis Methodology}

2.1. Aerosol Optical Depth from Hemispheric Transport of Air Pollution Modeling Experiments on SourceReceptor Relationships

[9] We use output from nine models (Table 1) that participated in the HTAP S/R modeling experiments, which aim to evaluate changes in concentration, loading, and climate impacts of aerosols in response to a $20 \%$ reduction of anthropogenic emissions in four major pollution regions in the Northern Hemisphere [Fiore et al., 2009; HTAP, 2010]. The major model outputs used in this study are monthly average $\mathrm{AOD}(\tau)$ at $550 \mathrm{~nm}$ for sulfate $\left(\mathrm{SO}_{4}\right), \mathrm{POM}$, and $\mathrm{BC}$, including both anthropogenic and natural component. Major characteristics of the models are summarized in Table S1 of the supporting information. Clearly, these models differ in several aspects. The models differ substantially in spatial resolutions, with horizontal resolution ranging from $1.125^{\circ}$ $\times 1.125^{\circ}$ to $5^{\circ} \times 4^{\circ}$, and the number of vertical model levels ranging from 19 to 48 . Most models are chemical transport models driven by different assimilated meteorological fields (National Centers for Environmental Prediction - NCEP, Goddard Earth Observing System Data Assimilation System, version 3 (GEOS-3), GEOS-4). Some models use meteorological fields from free-running General Circulation Models (GCMs). Common emissions among the models include $\mathrm{SO}_{2}$ from anthropogenic and volcanic sources, dimethyl sulfide (DMS) from ocean, and BC and POM from anthropogenic and biomass-burning sources. However, the emissions used in individual models often differ, with global annual emissions of 129.4 to $165.7,49.6$ to 84.7 , and 7.2 to 9.5 $\mathrm{Tg}$ for $\mathrm{SO}_{2}, \mathrm{POM}$, and $\mathrm{BC}$, respectively. Although some models consider direct emissions of sulfate particles and/ or biogenic POM, others do not. Emissions of gaseous pollutants are reported by Fiore et al. [2009]. The models also differ in aerosol chemistry. Four models use prescribed oxidants from tropospheric chemistry models to parameterize sulfur chemistry, whereas five models use prognostic oxidants from a fully coupled chemistry model. Secondary POM formation is generally highly simplified or even excluded in the models. The models also differ in parameterizations of wet scavenging processes, with some models considering in-cloud and below-cloud scavenging for convective clouds, whereas other do not. Converting aerosol mass concentrations to AOD depends on the mixture state and assigned optical properties. Although most models assume external mixing, two models consider internal mixing of some components. Databases for aerosol optical properties also differ from model to model. The majority of models assume all sulfate are aqueous phase ammonium sulfate without explicit inclusion of ammonia cycle. The omission of the hysteresis effect of sulfate particles would introduce significant uncertainty to the AOD and DRF [Tang, 1996; Wang et al., 2008]. A combination of different parameterizations of aerosol processes as outlined earlier can yield large diversities in modeled aerosol life cycle and AOD, which has been extensively documented [e.g., Kinne et al., 2006; Schulz et al., 2006; Textor et al., 2006, 2007; Koffi et al., 2012]. 


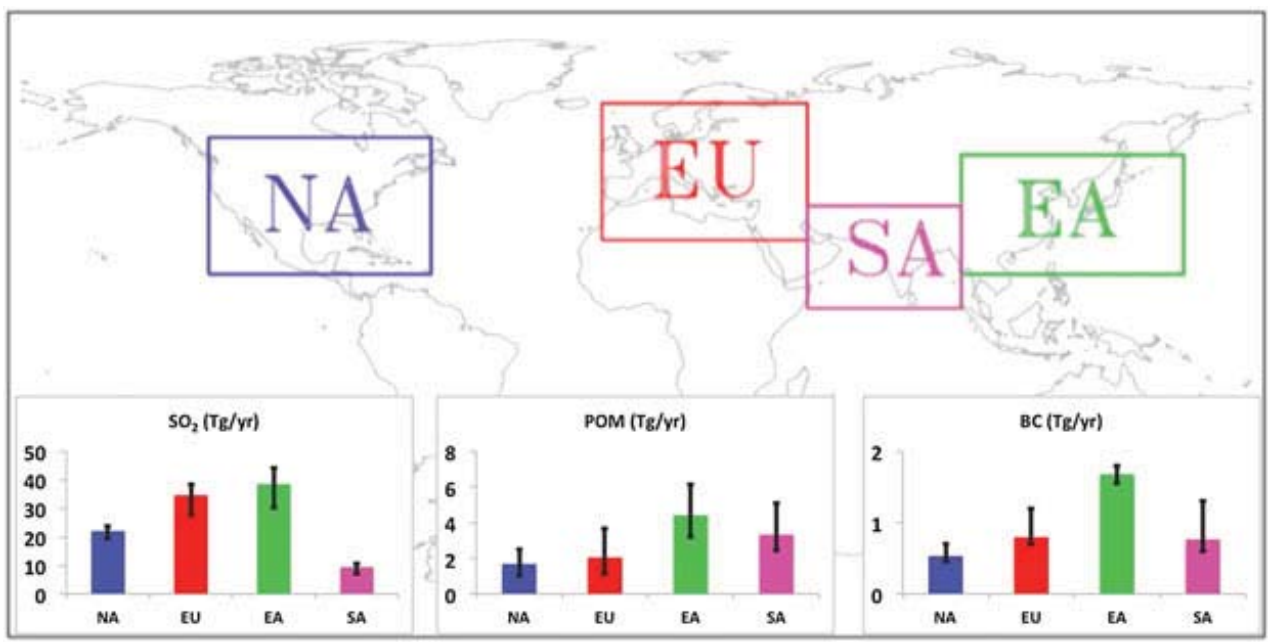

Figure 1. Four HTAP regions for examining the source-receptor relationships for anthropogenic aerosols: North America (NA, $15^{\circ}-55^{\circ} \mathrm{N}, 60^{\circ}-125^{\circ} \mathrm{W}$ ), Europe (EU, $\left.25^{\circ}-65^{\circ} \mathrm{N}, 10^{\circ} \mathrm{W}-50^{\circ} \mathrm{E}\right)$, East Asia $\left(\mathrm{EA}, 15^{\circ}-50^{\circ} \mathrm{N}, 95^{\circ}-160^{\circ} \mathrm{E}\right)$, and South Asia $\left(\mathrm{SA}, 5^{\circ}-35^{\circ} \mathrm{N}, 50^{\circ}-95^{\circ} \mathrm{E}\right)$. Regional and annual anthropogenic emissions of $\mathrm{SO}_{2}$, primary POM, and BC from seven models (excluding HadGEM2 and ECHAM5) are shown in bar charts, with error bar indicating the range of eight models.

[10] The HTAP S/R experiments include a baseline simulation and four perturbation simulations, for which each model submitted monthly AOD fields. For each model, the baseline simulation (SR1) is conducted using emissions and meteorology for 2001. Note that individual models used their own preferred anthropogenic and natural emissions. Each of the four perturbation runs (SR6) represents a $20 \%$ reduction in anthropogenic emissions of both gas-phase and aerosol components in one of the four major pollution regions, namely, North America (NA), Europe (EU), East Asia (EA), and South Asia (SA) (Figure 1). These perturbation model experiments are denoted as SR6NA, SR6EU, SR6EA, and SR6SA, respectively. In SR6 experiments, biomass-burning emissions are considered as completely anthropogenic sources. On a global mean basis, POM emitted from biomass burning smoke is nearly 3 times that emitted from burning biofuel and fossil fuels, whereas the $\mathrm{BC}$ emitted from biomass burning is about two-thirds the amount emitted from burning biofuel and fossil fuels [Dentener et al., 2006].

[11] Figure 2 shows the anthropogenic emissions for $\mathrm{SO}_{2}$, POM (primary only), and BC from seven models in the four major pollution regions (NA, EU, EA, and SA in Figure 1) and their fractional contributions to global total emissions. Emissions for Max-Planck Institute for Meteorology Hamburg Climate Model, version 5 (ECHAM5), and Hadley Centre Global Environment Model, version 2 (HadGEM2), were not archived and cannot be retrieved for this analysis. Also shown in Figure 2d are fractional contributions of the four-region total to global emissions. Clearly, anthropogenic emissions show large regional differences. For example, on average, SA has the least $\mathrm{SO}_{2}$ emissions that are a factor of 2 to 4 smaller than the other regions. EA has the largest $\mathrm{BC}$ emissions that are nearly double the emissions in EU or SA and more than triple the emissions in NA. The four-region total emission accounts for $72 \pm 5 \%, 21 \pm 10 \%$, and $46 \pm 6 \%$ of global emissions for $\mathrm{SO}_{2}, \mathrm{POM}$, and $\mathrm{BC}$, respectively. Although intermodel differences in emissions shown in Figure 2 would contribute to model differences in AOD and DRF, the differences in other aerosol processes among the models will factor in. As shown in Textor et al. [2007], harmonizing emissions may not significantly reduce model diversity in the aerosol life cycle.

\subsection{Estimate of the Aerosol Direct Radiative Forcing}

[12] The aerosol DRF or the aerosol optical properties (i.e., single-scattering albedo and asymmetry factor) for calculating the forcing are not archived under the HTAP S/R experiment protocol. We estimate here the aerosol DRF for each model and component $i$ (i.e., sulfate, POM, or BC), based on AOD reported by each model, as follows:

$$
D R F_{i}(x, y, t)=A O D_{i}(x, y, t) \times N D R F_{i}(x, y, t)
$$

where $x, y$, and $t$ represent longitude, latitude, and month, respectively, and NDRF is the normalized DRF with respect to AOD at $550 \mathrm{~nm}$ [Zhou et al., 2005]. In this study, we derive monthly average NDRF for each component over each model grid cell by dividing the DRF by the AOD, using 2001 monthly average AOD and DRF calculated from the Goddard Chemistry Aerosol Radiation and Transport (GOCART) model [Chin et al., 2002]. We then apply this $\mathrm{NDRF}_{i}$ to the monthly average component $\mathrm{AOD}_{i}$ from the other models in the HTAP S/R experiments that are regridded to the GOCART horizontal resolution of $2.5^{\circ} \times$ $2^{\circ}$. We also estimate DRF for an external mixture of $\mathrm{SO}_{4}$, POM, and BC by summing up the DRF for individual components. Note that RF for an internal mixture could differ from that for an external mixture by a factor of $\sim 2$ as revealed by laboratory experiments and model calculations [Jacobson, 2001; Chung and Seinfeld, 2002], whereas most recently, an in situ observation reports substantially less difference (on an order of $10 \%$ ) [Cappa et al., 2012]. Although DRF does not increase with AOD in a fully linear manner over the whole range of AOD, the function would be close to linear for AOD changes on the order of $20 \%$, and the use of the above linear relationship to derive the 


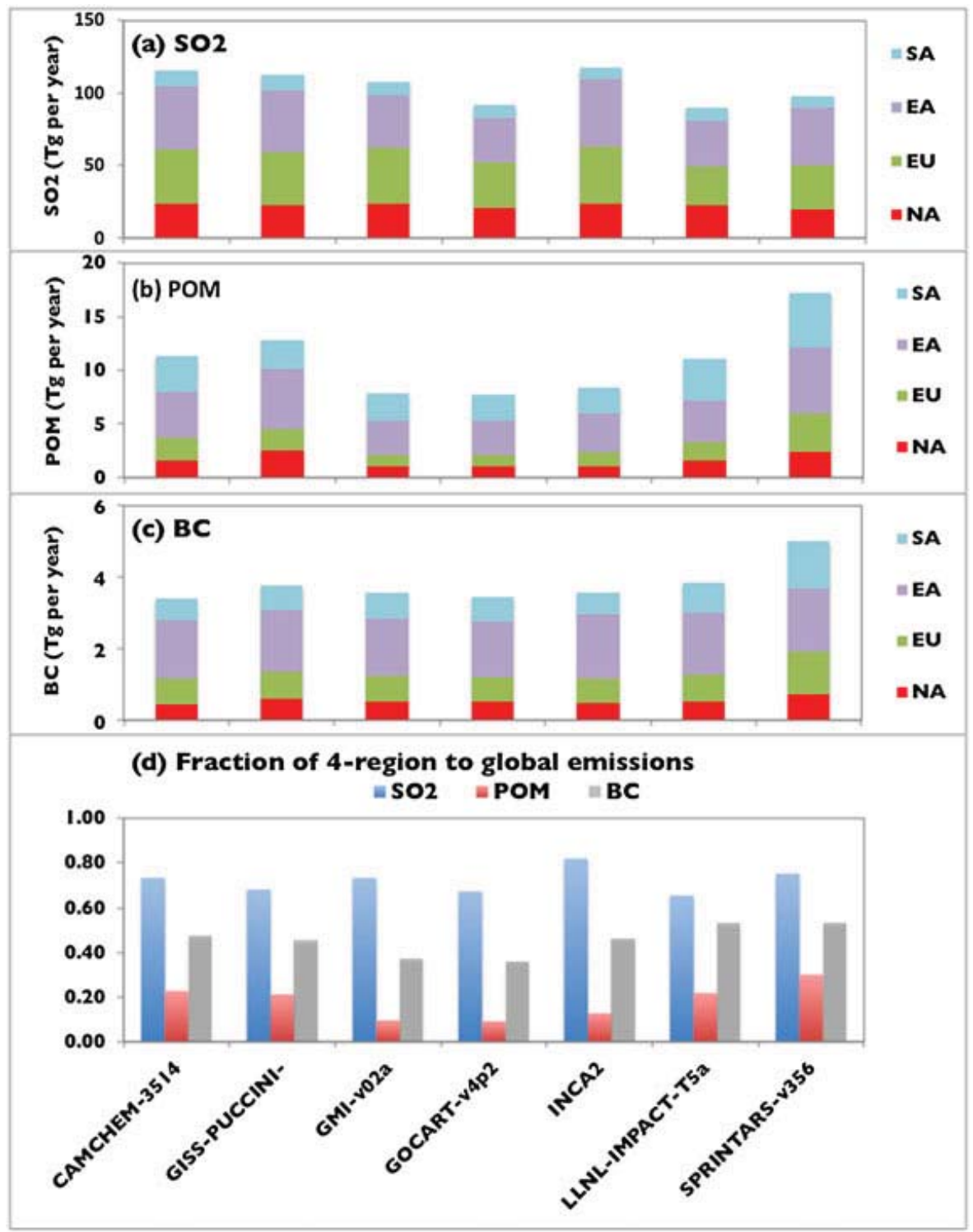

Figure 2. Regional emissions of (a) $\mathrm{SO}_{2}$, (b) POM, and (c) BC in North America (NA), Europe (EU), East Asia (EA), South Asia (SA) used by seven models in HTAP SR1 simulations. The four regions NA, EU, EA, and SA are defined in Figure 1. (d) Fractional contributions of the four-region total to global emissions.

DRF change in response to a $20 \%$ reduction of emissions would not introduce large uncertainties with respect to regional differences in DRF [Zhou et al., 2005; Anderson et al., 2005].

[13] The GOCART model currently prescribes particle size distributions and refractive indices for individual components based on the Optical Properties of Aerosols and Clouds (OPAC) database [Hess et al., 1998]. Aerosol properties such as AOD, single-scattering albedo, and asymmetry factor are then calculated using the Mie code at different levels of relative humidity [Chin et al., 2002, 2009]. In GOCART, all sulfate is assumed to be ammonium sulfate and in aqueous phase. The omission of hysteresis effect of sulfate particles would introduce $10 \%$ to $30 \%$ of uncertainty to aerosol DRF [Wang et al., 2008]. GOCART model assumes that $80 \%$ of BC and $50 \%$ of POM are hydrophobic, with the rest being hydrophilic [Chin et al., 2002]. These aerosol optical properties along with surface albedos and cloud fields from the GEOS-4 are then used to drive the National Aeronautics and Space Administration (NASA) Goddard radiative transfer model [Chou et al., 1998]. The time step for the radiative transfer calculations is 30 minutes, which can adequately capture the dependence of DRF on solar zenith angle [ $\mathrm{Yu}$ et al., 2004]. For a specific component (e.g., $\mathrm{SO}_{4}, \mathrm{POM}$, or $\mathrm{BC}$ ), DRF is calculated as the difference of net downward radiative flux between a radiative transfer calculation including all aerosol components and one with the specific component excluded. This DRF is therefore different from the DRF estimated in Forster et al. [2007], where the reference is preindustrial aerosols. However, this study focuses on the NDRF that does not depend strongly on a selection of the reference state. In this study, the GOCART DRF is calculated for solar radiation only and averaged over a 24 hour period. 
[14] GOCART calculations of DRF have been evaluated against remote sensing measurements and other model simulations [e.g., Yu et al., 2004, 2006]. Table 2 lists the annual mean NDRF in the four defined regions and globally. For purely scattering $\mathrm{SO}_{4}, \mathrm{DRF}$ at TOA is very similar to that at the surface. Because POM is partially absorbing in the ultraviolet range [Chin et al., 2009], the surface NDRF is more negative than the TOA NDRF. BC aerosol is strongly absorbing over the whole solar spectrum, thus its TOA forcing is positive (i.e., warming of the Earth-atmosphere system), whereas the surface forcing is strongly negative (i.e., surface cooling). Clearly, BC aerosol is much more effective in interacting with solar radiation than are $\mathrm{SO}_{4}$ and POM, although it is typically associated with lower AODs. For a specific component, the difference in NDRF among regions is generally within $20 \%$ to $30 \%$, due to the combined effects of differences in solar zenith angle, surface albedo, and cloud fields [Yu et al., 2006]. The global annual mean all-sky TOA NDRF from GOCART is -24 , -30 , and $+86 \mathrm{~W} \mathrm{~m}^{-2} \tau^{-1}$ for $\mathrm{SO}_{4}, \mathrm{POM}$, and $\mathrm{BC}$, respectively. These values fall within the ranges reported in the literature, i.e., -10 to $-32 \mathrm{~W} \mathrm{~m}^{-2} \tau^{-1}$ for $\mathrm{SO}_{4},-5$ to $-38 \mathrm{~W} \mathrm{~m}^{-2} \tau^{-1}$ for POM, and +22 to $+216 \mathrm{~W} \mathrm{~m}^{-2} \tau^{-1}$ for BC [Schulz et al., 2006; Forster et al., 2007]. In comparison to the median values from most recent Aerosol Comparisons between Observations and Models (AeroCom) Phase 2 model simulations [Myhre et al., 2012], the TOA all-sky NDRF used in this study is more negative for sulfate (by $42 \%$ ) and POM (by $30 \%$ ), but less positive for BC (by $32 \%$ ). These biases are primarily due to the low bias of the GEOS-4 cloud fraction used in the GOCART model [Myhre et al., 2012; Stier et al., 2012].

[15] We note that the use of GOCART-based NDRF may understate the model diversity in DRF, in comparison to that derived from full radiative transfer calculations by participating models. Models can differ in aerosol microphysical and optical properties, as reflected in Table S1. Models can also differ substantially in aerosol vertical distributions, meteorological fields (such as relative humidity, cloud distributions, and surface albedos), and radiative transfer schemes. These differences combined may lead to large model differences in DRF [Stier et al., 2012; Myhre et al., 2012]. The differences could be particularly important for all-sky TOA DRF by
BC, which depends strongly on the vertical distributions of aerosol and clouds [Samset and Myhre, 2011], as evidenced by the reported wide range of DRF [U.S. Climate Change Science Program, 2009, and references therein]. An assumption implicit in equation (1) is that NDRF does not depend on the vertical distribution of aerosols. The assumption could introduce large uncertainties to the all-sky TOA DRF for $\mathrm{BC}$, because $\mathrm{BC}$ at higher altitudes is more efficient in absorbing solar radiation at higher altitude than at lower altitude [Samset and Myhre, 2011]. Given that the transported aerosols often stay above the local aerosols [Chin et al., 2007; Huang et al., 2012; Yu et al., 2012a], the relative role of aerosol (BC in particular) ICT in this study is likely to be underestimated.

\subsection{A Metric for Measuring the Role of Aerosol Intercontinental Transport}

[16] To quantify the role of aerosol ICT in affecting regional climate forcing, we adopt a concept of relative annual intercontinental response (RAIR) as defined in HTAP [2010]. For AOD, RAIR in a receptor region $i$ is expressed as follows:

$$
R A I R_{i}=\frac{\sum_{j, j \neq i} \delta A O D_{j i}}{\delta A O D_{i i}+\sum_{j, j \neq i} \delta A O D_{j i}}
$$

where index $j$ represents a source region, $\delta \mathrm{AOD}_{i i}$ represents a change of AOD in the receptor/domestic region $i$ due to the emission reduction in the region itself, and $\delta \mathrm{AOD}_{j i}$ represents a change of AOD in the receptor $i$ induced by the emission reduction in a source region $j$ outside of the receptor (or foreign region). Similarly, RAIR can be defined for DRF, near-surface concentration, and surface deposition. By definition, RAIR in a receptor region represents the percentage contribution of the ICT of foreign emissions relative to the sum of foreign and domestic emissions. A larger RAIR indicates a greater relative contribution of aerosol ICT.

\section{Results}

[17] In this section, we first present baseline (SR1) simulations of AOD and DRF, and their comparisons with

Table 2. Annual Mean Aerosol Direct Radiative Forcing Normalized by Aerosol Optical Depth at $550 \mathrm{~nm}$ (Normalized Direct Radiative Forcing, $\mathrm{W} \mathrm{m}^{-2} \tau^{-1}$ ) at Top of Atmosphere and Surface for Sulfate, Particulate Organic Matter, and Black Carbon in the Four Source Regions (North America, Europe, East Asia, and South Asia) and Globe, Derived From Goddard Chemistry Aerosol Radiation and Transport Simulated Monthly Aerosol Optical Depth and Direct Radiative Forcing for $2001^{\mathrm{a}}$

\begin{tabular}{|c|c|c|c|c|c|c|c|}
\hline \multirow[b]{2}{*}{ Sky Condition } & \multirow[b]{2}{*}{ Region } & \multicolumn{2}{|c|}{$\mathrm{NDRF}_{\mathrm{SO} 4}$} & \multicolumn{2}{|c|}{$\mathrm{NDRF}_{\mathrm{POM}}$} & \multicolumn{2}{|c|}{$\mathrm{NDRF}_{\mathrm{BC}}$} \\
\hline & & TOA & Surface & TOA & Surface & TOA & surface \\
\hline \multirow[t]{5}{*}{ All Sky } & NA & -24.9 & -24.5 & -28.4 & -39.1 & 84.6 & -225.2 \\
\hline & EU & -21.1 & -20.4 & -22.6 & -32.8 & 93.0 & -190.8 \\
\hline & EA & -21.4 & -21.2 & -25.4 & -35.1 & 83.2 & -210.0 \\
\hline & SA & -24.9 & -25.1 & -28.7 & -41.0 & 89.6 & -235.2 \\
\hline & Globe & -24.2 & -24.1 & -30.0 & -41.5 & 85.9 & -231.6 \\
\hline \multirow{4}{*}{ Clear Sky } & EU & -25.6 & -24.6 & -27.9 & -37.9 & 80.2 & -207.8 \\
\hline & EA & -26.6 & -26.3 & -32.1 & -41.5 & 59.9 & -231.3 \\
\hline & SA & -27.7 & -27.8 & -32.7 & -44.8 & 74.6 & -247.6 \\
\hline & Globe & -30.2 & -29.9 & -37.0 & -48.4 & 62.8 & -252.7 \\
\hline
\end{tabular}

${ }^{\mathrm{a} B C}$, black carbon; EA, East Asia; EU, Europe; NA, North America; NDRF, normalized direct radiative forcing; POM, particulate organic matter; SA, South Asia; $\mathrm{SO}_{4}$, sulfate; TOA, top of atmosphere. 
Moderate Resolution Imaging Spectroradiometer (MODIS) estimates and those in the literature based on a multimodel analysis. Then we present how the $20 \%$ reduction of regional anthropogenic emissions changes AOD and DRF by analyzing differences between a set of SR6 experiments (SR6NA, SR6EU, SR6EA, and SR6SA) and the SR1 experiment. We examine the changes in global mean AOD and DRF, and then the spatial extents of AOD and DRF changes resulting from regional anthropogenic emission reductions. The relative roles of ICT and regional emissions are assessed using the RAIR.

\subsection{Baseline Simulations of Aerosol Optical Depth and Direct Radiative Forcing}

[18] Figure 3 shows annual average AOD in ambient conditions for a combination of $\mathrm{SO}_{4}, \mathrm{POM}$, and $\mathrm{BC}$ from SR1 simulations of eight models (seasonal average AOD is shown in the supporting information, Figures S1a to S1d). ECHAM5 simulations are not shown in this article because the model calculates AOD for dry sulfate, POM, and BC. Although the model also provides water optical depth associated with total aerosol (e.g., due to aerosol humidification), it is impossible, without further uncertain assumptions, to partition the water optical depth into that associated with individual aerosol components. Note that these AOD outputs include both anthropogenic and natural contributions (e.g., DMS-derived sulfate AOD, wild-fire AOD, among others). The AOD distributions clearly show several hot spots representing well-known industrial pollution regions (e.g., EA, SA, Western Europe, and eastern United States) and biomass-burning regions (e.g., equatorial Africa in December-January-February (DJF), South America, and southern Africa in June-July-August (JJA) and SeptemberOctober-November (SON)). The global and annual mean total AOD ranges from 0.024 to 0.066 . The global annual mean $\mathrm{AOD}$ is $0.0352 \pm 0.0132$ (average \pm standard deviation of 8 models), $0.0112 \pm 0.0048$, and $0.0022 \pm 0.0010$ for $\mathrm{SO}_{4}$, POM, and BC, respectively (Table 3). Clearly, AOD shows large model diversity, especially for POM and BC in which the standard deviation is equivalent to about half of the multimodel average. Because biomass burning makes a major contribution to $\mathrm{POM}$ and $\mathrm{BC}$, the intermodel variability may reflect large variability of biomass-burning emissions used in the models. In comparison to those from multiple model simulations with harmonized emissions under the framework of the AeroCom [Schulz et al., 2006], AOD in this study is higher by $12 \%$, lower by $25 \%$, and lower by $8 \%$ for sulfate, POM, and BC, respectively. These AOD differences

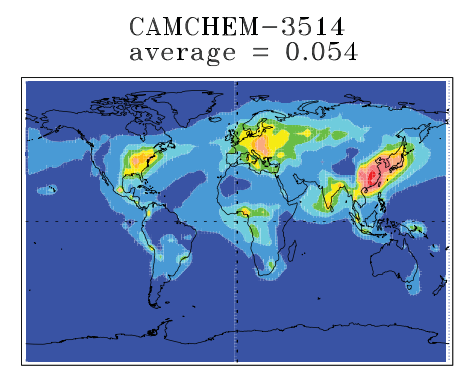

GISS-PUCCINI-modelEaer average $=0.052$

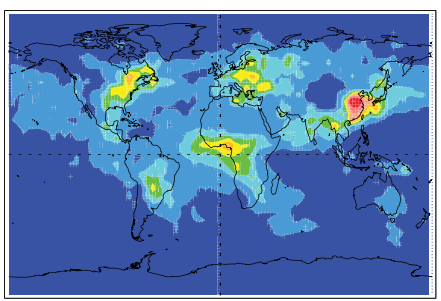

GOCART $-\mathrm{v} 4 \mathrm{p} 2$ average $=0.061$

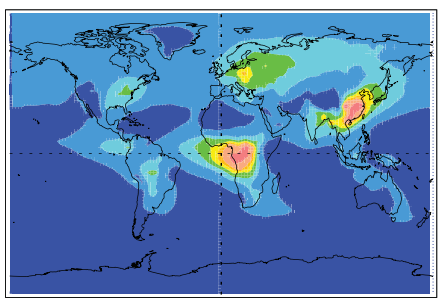

LLNL-IMPACT-T5a average $=0.037$
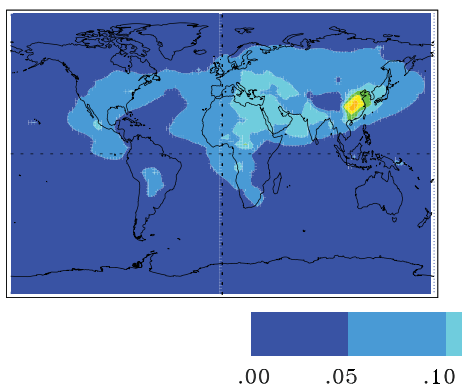

HADGEM $2-\mathrm{A}-\mathrm{v} 01$ average $=0.024$

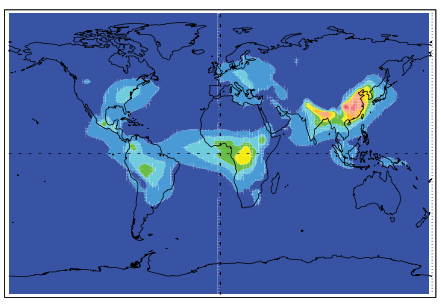

SPRINTARS-v356 average $=0.034$

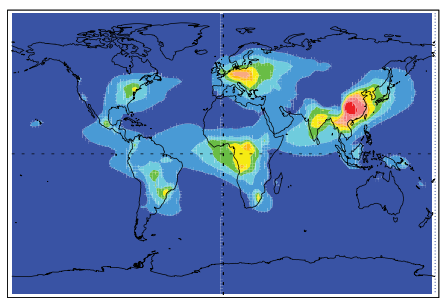

GMI-v02a average $=0.066$

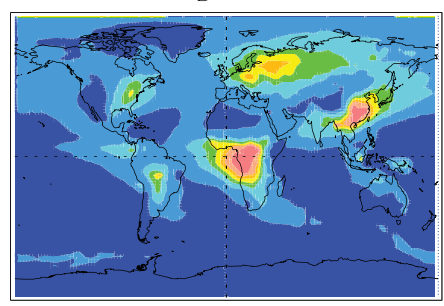

INCA-V2 average $=0.056$

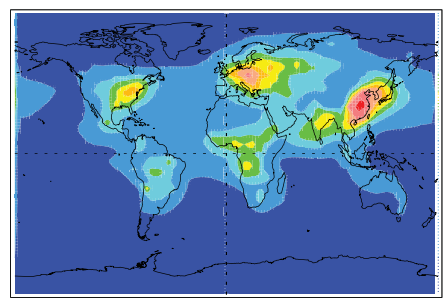

8-model Median average $=0.050$

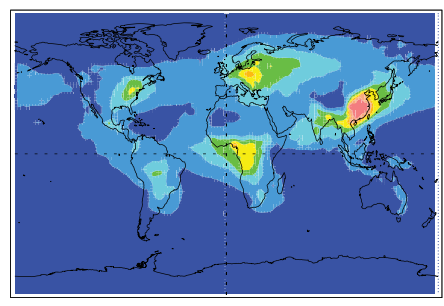

.40 $.60 \quad 1.0$

Figure 3. Annual average AOD for the external mixture of sulfate, POM, and BC simulated by baseline runs of individual models and eight-model median. 
Table 3. Comparisons of Total (Natural + Anthropogenic) Aerosol Optical Depth at $550 \mathrm{~nm}(\tau)$ From Eight Hemispheric Transport of Air Pollution Models in This Study With That From Schulz et al. $[2006]^{\mathrm{a}}$

\begin{tabular}{lcc}
\hline & This Study & Schulz et al. $[2006]$ \\
\hline AOD & & \\
$\tau_{\text {SO4 }}$ & $0.0352 \pm 0.0132$ & $0.0300 \pm 0.0149$ \\
$\tau_{\text {POM }}$ & $0.0112 \pm 0.0048$ & $0.0144 \pm 0.0092$ \\
$\tau_{\mathrm{BC}}$ & $0.0022 \pm 0.0010$ & $0.0024 \pm 0.0010$ \\
Emissions $(T g)$ & & \\
$\mathrm{SO}_{2}$ & $145 \pm 13$ & 220 \\
$\mathrm{POM}$ & $64 \pm 14$ & 47 \\
$\mathrm{BC}$ & $8.4 \pm 1.1$ & 7.7 \\
\hline
\end{tabular}

${ }^{\mathrm{a}}$ For black carbon (BC), we infer aerosol optical depth (AOD) from the anthropogenic absorptive AOD reported in Schulz et al. [2006] by assuming that all $\mathrm{BC}$ is anthropogenic and $\mathrm{BC}$ has a single scattering albedo of 0.2 at $550 \mathrm{~nm}$. Emissions used in this study (eight-model average) and by Schulz et al. [2006] (using harmonized emissions from Dentener et al. [2006]) are also listed.

are not consistent with differences in emissions of $\mathrm{SO}_{2}, \mathrm{POM}$, and BC as shown in Table 3. Presumably, differences in other aerosol processes contribute to the AOD difference.

[19] Evaluating the model simulated AOD for sulfate, POM, and BC with large-scale observations (e.g., from satellites) remains difficult, because satellites usually observe total AOD. Comparison with MODIS fine-mode AOD can be complicated by substantial contributions of fine-mode dust and sea salt [Bates et al., 2001; Kaufman et al., 2005; Yu et al., 2009]. Some recent studies have attempted to derive anthropogenic AOD over the oceans from MODIS measurements of total AOD and fine-mode fraction (FMF) [Kaufman et al., 2005; Bellouin et al., 2005, 2008; Yu et al., 2009]. Figure 4a shows the eightmodel median AOD for sulfate, POM, and BC combined as derived from the SR1 baseline simulations and its comparisons with anthropogenic AOD derived from MODIS over-ocean measurements using two different methods described by $Y u$ et al. [2009] (Figure 4b, denoted as MODIS-YU09) and Bellouin et al. [2008] (Figure 4c, denoted as MODIS-BE08). In both methods, total AOD is a sum of three components: anthropogenic aerosol (including pollution and biomass-burning smoke), dust aerosol, and marine aerosol (including sea salt, DMS-oxidized sulfate, and marine organic particle). It is assumed that carbonaceous aerosols from biogenic emissions do not make significant contributions over oceans. MODIS-YU09 anthropogenic AOD is derived from MODIS over-ocean retrievals of AOD and FMF using the representative FMF values for individual aerosol types, which are determined from MODIS (a) HTAP-median

DJF

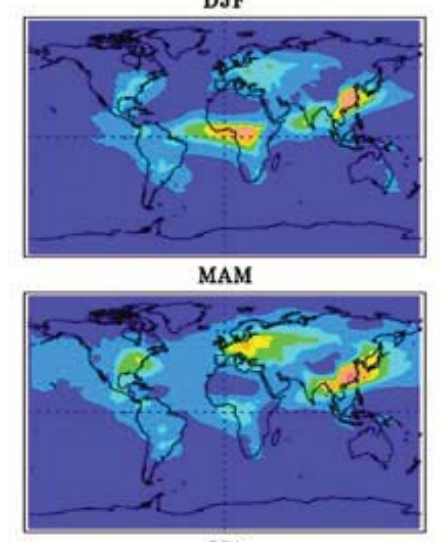

JJA

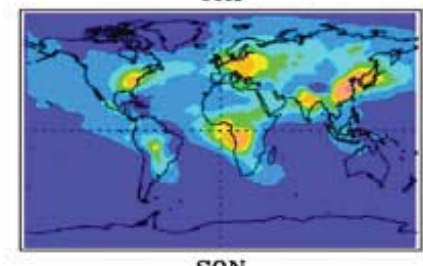

SON

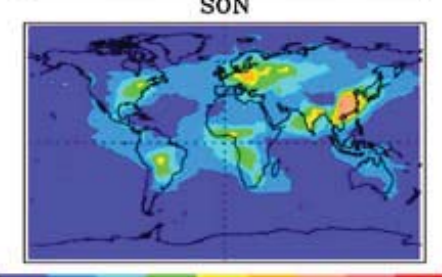

(b) MODIS-YU09
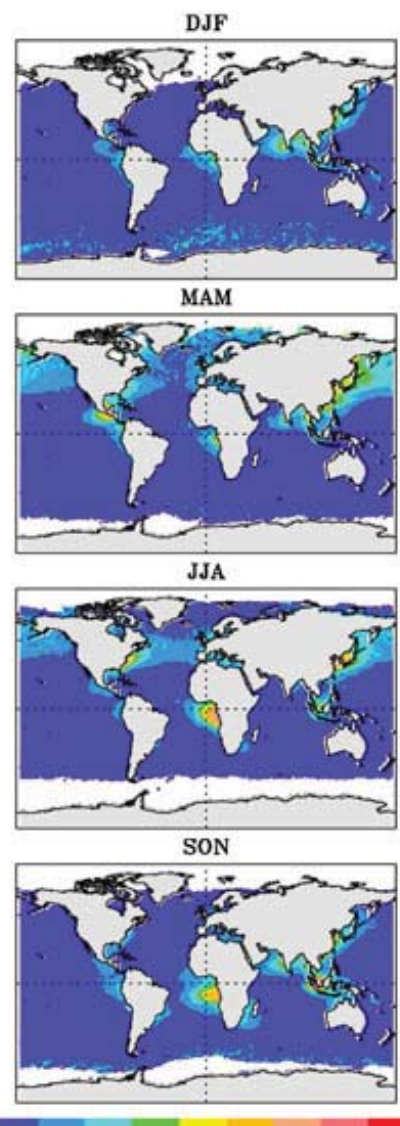

(c) MODIS-BE08
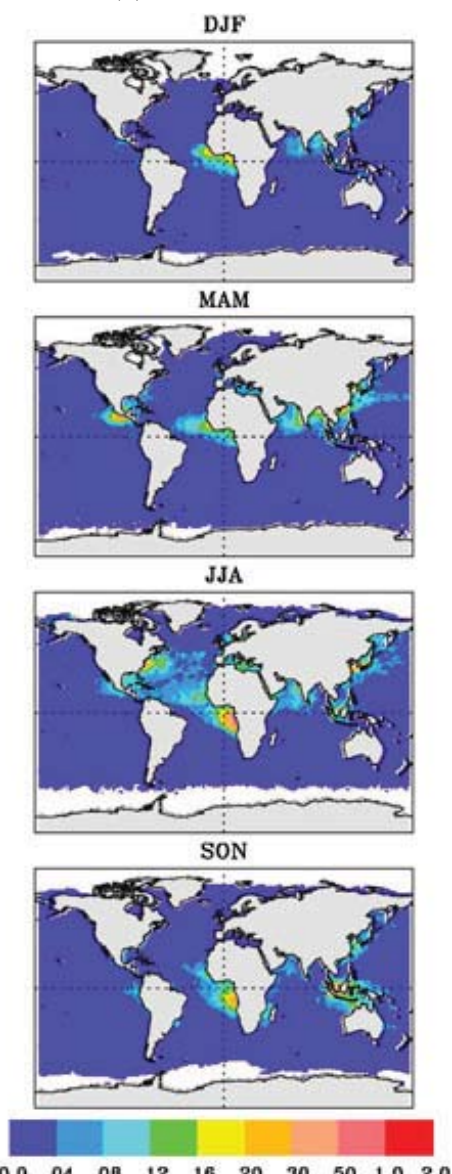

$\begin{array}{llllllllllllllllllllllllllllll}.00 & .04 & .08 & .12 & .16 & .20 & .30 & .50 & 1.0 & 2.0 & 0.0 & .04 & .08 & .12 & .16 & .20 & .30 & .50 & 1.0 & 2.0 & 0.0 & .04 & .08 & .12 & .16 & .20 & .30 & .50 & 1.0 & 2.0\end{array}$

Figure 4. Comparison of HTAP SR1 eight-model median AOD for the external mixture of sulfate, POM, and BC (a) with MODIS-derived anthropogenic AOD over ocean as described in $\mathrm{Y} u$ et al. [2009] (b) and Bellouin et al. [2008] (c). 


\section{YU ET AL.: AEROSOL INTERCONTINENTAL TRANSPORT}

observations in selected regions where the specific aerosol type predominates [Yu et al., 2009]. MODIS-BE08 is derived from the same MODIS measurements, but with the use of prescribed, in situ measurement-based thresholds of FMF for different aerosol types (which are different from those derived from MODIS observations as in $Y u$ et al., 2009) aided by the satellite observed absorbing aerosol index to separate anthropogenic aerosol from mineral dust and sea salt [Bellouin et al., 2008]. Deriving anthropogenic AOD over land from satellite measurements alone is not currently feasible. As shown in Figure 4, anthropogenic AOD of MODIS-YU09 is generally larger than MODIS-BE08 AOD in northern hemispheric midlatitudes. In the tropics, MODIS-BE08 AOD is somewhat higher than MODISYU09. Except for trans-Pacific transport in spring, the cross-ocean transport from major industrial pollution and biomass-burning regions is generally more extensive in the HTAP model simulations than both MODIS-based estimates, which is generally consistent with the inclusion of natural sulfate and POM in the model simulations. In particular, the models simulated significant cross-Atlantic transport of tropical African smoke to South America in boreal winter, which is not clearly seen in the MODIS-based estimates. As discussed in Yu et al. [2009], distinguishing smoke from dust in MODIS observations in the tropical Atlantic remains a challenge, and further study with measurements from multiple sensors on A-Train is needed.

[20] Figure 5 compares zonal variations of HTAP seasonal AOD for the sulfate, POM, and BC mixture against that of the MODIS anthropogenic AOD over the ocean in Northern Hemisphere midlatitudes $\left(20^{\circ}-60^{\circ} \mathrm{N}\right)$, where the major ICT paths occur. Although uncertainties associated with satellite estimates are expected to be large, it is difficult to quantify due to the lack of ground-truth measurements. Significant regional and seasonal differences exist between the HTAP models and MODIS observations, and between
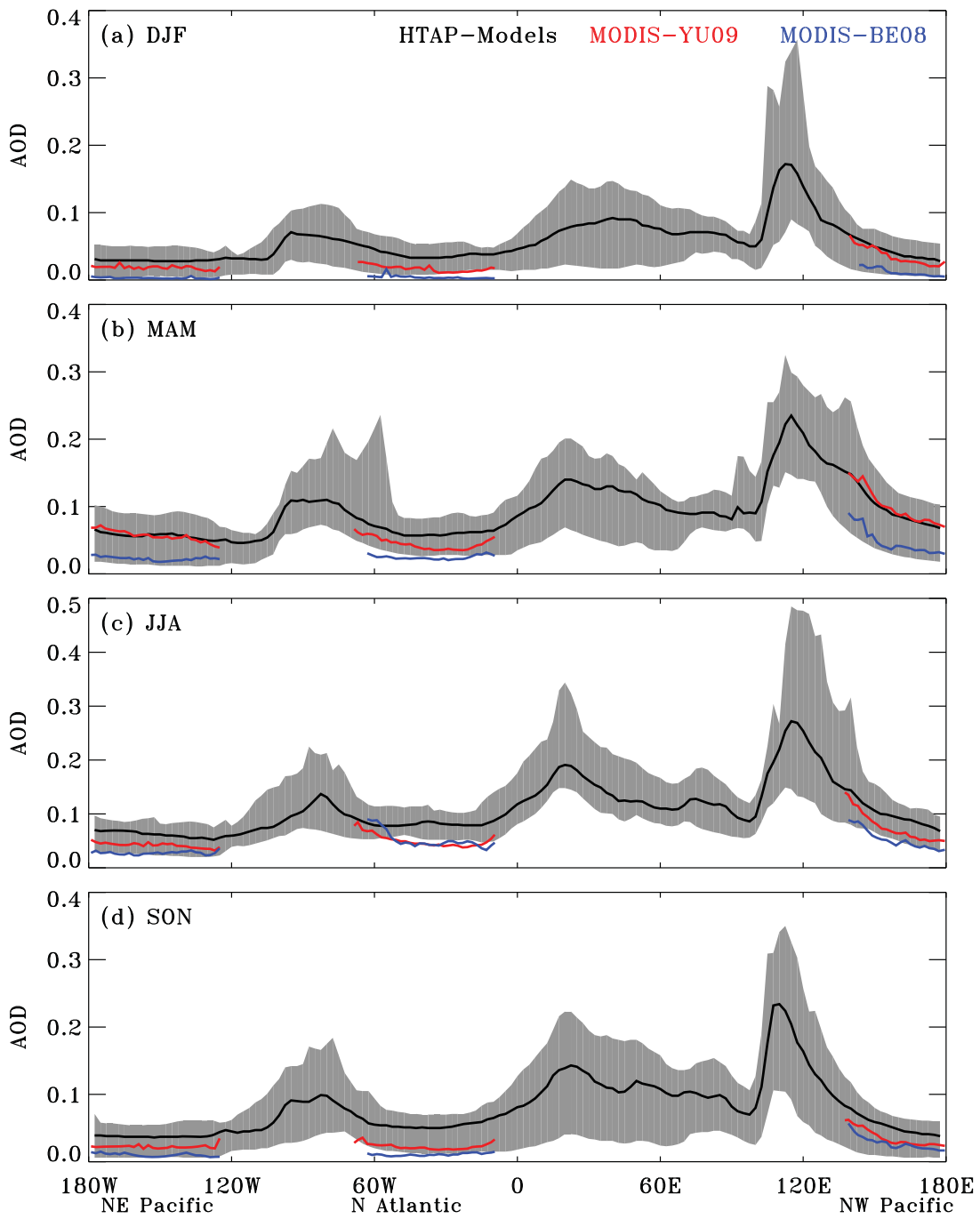

Figure 5. Comparisons of zonal variations of $20^{\circ} \mathrm{N}-60^{\circ} \mathrm{N}$ average AOD for sulfate, POM, and BC combined as simulated by HTAP models (black line for median and shaded area for the range of eight models) with the MODIS-derived over-ocean anthropogenic AOD (red line for Yu et al., 2009; blue line for Bellouin et al., 2008) for DJF (a), MAM (b), JJA (c), and SON (d). Note that HTAP model results cover both land and ocean, whereas MODIS-based anthropogenic AOD were estimated only over ocean. AODs from individual models are shown in Figure S2 of the supporting information. 
MODIS-YU09 and MODIS-BE08. In the North Atlantic, the MODIS anthropogenic AOD from both methods is often near the low bound of eight HTAP models. In the North Pacific, MODIS-YU09 anthropogenic AOD generally agrees well with the median of HTAP models. On the other hand, MODIS-BE08 is consistently lower than MODISYU09 and generally consistent with the low bound of the HTAP model simulations, particularly in the northeastern Pacific. Note that the model simulations are expected to be larger than satellite estimates, as the models include natural components of sulfate and POM. Based on Schulz et al. [2006], global mean AOD is 0.0086 and 0.0038 for natural sulfate and natural POM, respectively. If the natural components in model simulations were accounted for, model-satellite differences would generally decrease.

[21] The total all-sky aerosol DRF exhibits large regional and seasonal variations (Figure 6) for the external mixture of $\mathrm{SO}_{4}, \mathrm{POM}$, and $\mathrm{BC}$, as derived from the eight-model SR1 simulations. Over major industrial pollution regions in northern hemispheric midlatitudes, aerosol DRF can be as large as $-6 \mathrm{~W} \mathrm{~m}^{-2}$ at TOA and $-25 \mathrm{~W} \mathrm{~m}^{-2}$ at the surface. The forcing in industrial regions is greater (more negative) in JJA and March-April-May (MAM) than in DJF and SON, which is generally consistent with seasonal variations of AOD (see Figure 4a). Similar magnitudes of DRF are seen in the tropics where biomass-burning smoke is dominant. The seasonal variations of DRF reflect the peak seasons of biomass burning, e.g., DJF in the Sahel, and JJA and SON in southern Africa and South America. Positive TOA DRF does not appear in Figure 5 because the GEOS-4 cloud fraction is biased low [Myhre et al., 2012; Stier et al., 2012]. On a global and annual basis, the eight models give the all-sky TOA DRF of $-0.77 \pm 0.27,-0.29 \pm 0.12$, and $+0.23 \pm 0.12 \mathrm{~W} \mathrm{~m}^{-2}$ for $\mathrm{SO}_{4}, \mathrm{POM}$, and $\mathrm{BC}$, respectively. Correspondingly, the respective DRF at the surface and in all-sky (including both cloudy and cloud-free) condition is $-0.74 \pm 0.25$, $-0.40 \pm 0.17$, and $-0.46 \pm 0.20 \mathrm{~W} \mathrm{~m}^{-2}$. These results compare reasonably well with anthropogenic TOA DRF of $-0.35 \pm 0.15 \mathrm{~W} \mathrm{~m}^{-2}\left(\mathrm{SO}_{4}\right),-0.13 \pm 0.05 \mathrm{~W} \mathrm{~m}^{-2}$ (POM), and $+0.25 \pm 0.09$ (BC) $\mathrm{W} \mathrm{m}^{-2}$ reported by Schulz et al.
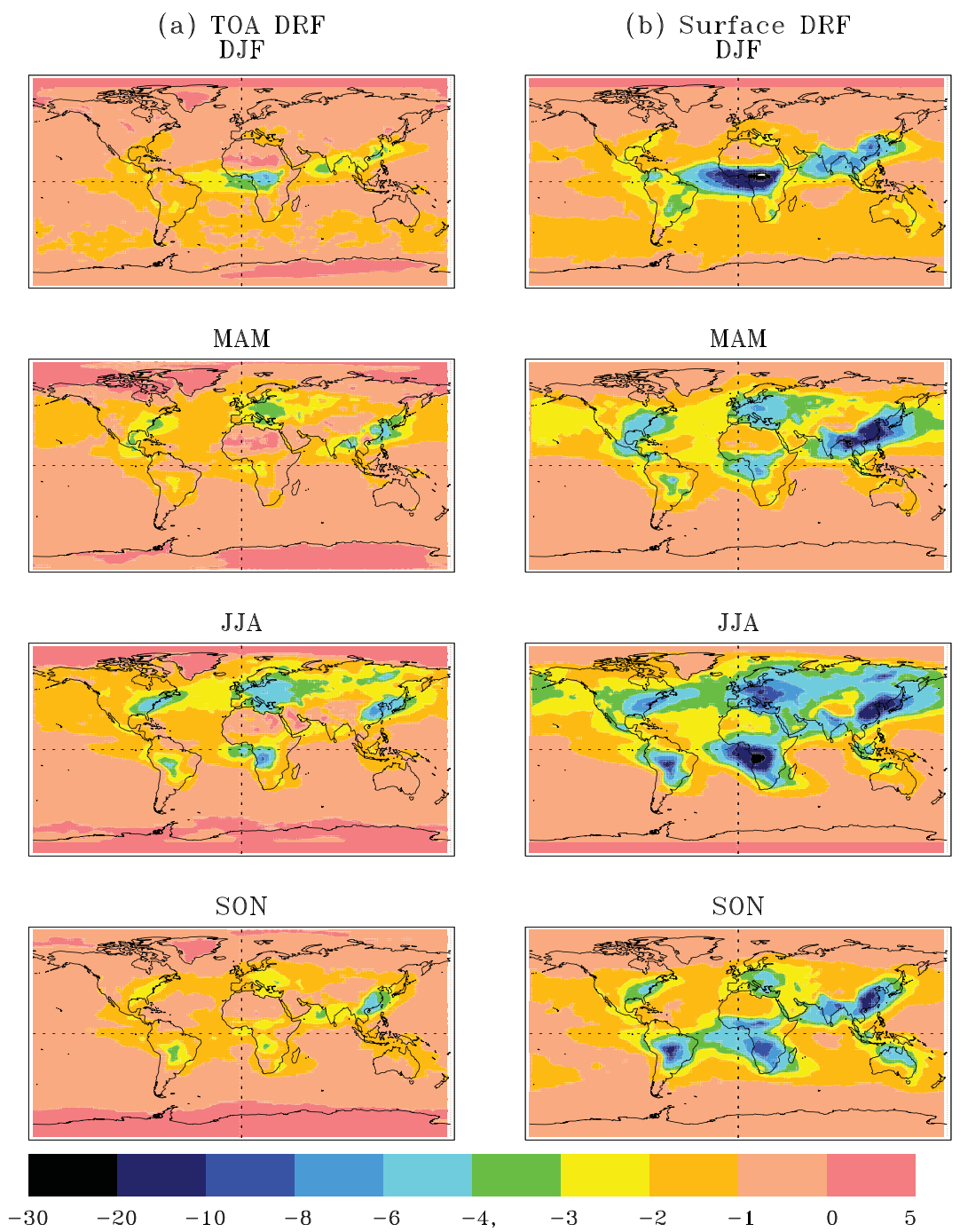

Figure 6. Seasonal variations of eight-model median TOA DRF (a) and surface DRF (b) in all-sky conditions $\left(\mathrm{W} \mathrm{m}^{-2}\right)$ for the external mixture of sulfate, POM, and $\mathrm{BC}$ as derived from the HTAP baseline simulations (SR1). 
[2006], given that the anthropogenic fraction of AOD is 55\%, $53 \%$, and $100 \%$, respectively, for $\mathrm{SO}_{4}, \mathrm{POM}$, and $\mathrm{BC}$ on a global and annual average basis [Schulz et al., 2006].

\subsection{Response of Global Mean Aerosol Optical Depth and Direct Radiative Forcing to the Emission Reduction}

[22] Just as aerosol RF varies regionally, the effects of changes in emissions of aerosols and their precursors on global mean DRF also varies with region. Tables 4 and 5 list, respectively, changes of global annual average AOD and all-sky DRF (both absolute magnitude and percentage change) in response to the $20 \%$ reduction of anthropogenic emissions in the four HTAP anthropogenic source regions. The combined impact of the $20 \%$ reduction of emissions in all of the four regions is to decrease global average AOD by $9.2 \%, 3.5 \%$, and $9.4 \%$ for sulfate, POM, and BC, respectively. Corresponding percentages for DRF are quite similar (Table 5). Relative contributions from individual regions vary considerably. For sulfate, the change of global average $\mathrm{AOD}$ and DRF due to the reduction of $\mathrm{SO}_{2}$ emissions in SA is substantially smaller than that due to the emission reductions from the other regions. This is mainly because $\mathrm{SO}_{2}$ emissions in the SA region are much smaller than those in other regions (see Figure 2). For POM, the reductions of global mean AOD and DRF due to the regional emission reduction are generally consistent with regional differences in primary POM emissions, similar to the findings of Henze et al. [2012]. For BC, the reduction of emissions in EA makes the largest contribution to the change of global aver- age DRF, mainly because of the highest $\mathrm{BC}$ emissions among the four regions. For the external mixture of $\mathrm{SO}_{4}$, POM, and BC, the $20 \%$ reductions in the anthropogenic emissions in the four regions collectively yield the respective reductions of $0.0038 \pm 0.0011,55.1 \pm 26.0 \mathrm{~mW} \mathrm{~m}^{-2}$, and $118.3 \pm 25.6 \mathrm{~mW} \mathrm{~m}^{-2}$ for global mean AOD, all-sky $\mathrm{DRF}$ at TOA, and at the surface, which represents about $8.0 \%, 6.7 \%$, and $7.5 \%$ reduction from the baseline simulation. Note that actual variability of DRF may be larger than given by the standard deviation in Table 5, due to the use of NDRF from a single model, as discussed earlier.

[23] Will the same amount of emission reduction in different regions introduce the same change in global mean aerosol RF? To address this question, we calculate the forcing efficiency with respect to emissions by normalizing the global annual mean DRF difference between the SR6 and SR1 runs by the change $(20 \%)$ in regional emissions for each model, as shown in Table 6. For $\mathrm{SO}_{4}$ and POM, we use the emissions for $\mathrm{SO}_{2}$ and primary POM to calculate the forcing efficiency. These derived forcing efficiency numbers should be considered as rough estimates, because some models with fully coupled chemistry include changes of $\mathrm{SO}_{4}$ resulting from the reductions of other anthropogenic emissions [Fry et al., 2012], and a fraction of POM is secondary aerosol formed from volatile organic carbon emissions. For the four-region total, the forcing efficiency is $-3.5 \pm 0.8,-4.0 \pm 1.7$, and $29.5 \pm 18.1 \mathrm{~mW} \mathrm{~m}^{-2}$ per $\mathrm{Tg}$ for sulfate, $\mathrm{POM}$, and $\mathrm{BC}$, respectively. The forcing efficiency for $\mathrm{BC}$ is nearly an order of magnitude higher than

Table 4. Change of Global Annual Mean All-Sky Aerosol Optical Depth $(\tau \times 1000$, mean \pm standard deviation) in Response to the $20 \%$ Reduction of Anthropogenic Emissions in Four Source Regions (SR6-SR1) of Eight Hemispheric Transport of Air Pollution Models ${ }^{\mathrm{a}}$

\begin{tabular}{lcrr}
\hline Source Region & $\Delta \tau_{\mathrm{SO} 4}$ & $\Delta \tau_{\mathrm{POM}}$ & $\Delta \tau_{\mathrm{BC}}$ \\
\hline NA & $-0.71 \pm 0.22(2.0 \%)$ & $-0.055 \pm 0.039(0.5 \%)$ & $-0.025 \pm 0.014(1.1 \%)$ \\
EU & $-1.18 \pm 0.47(3.4 \%)$ & $-0.084 \pm 0.062(0.8 \%)$ & $-0.051 \pm 0.022(2.4 \%)$ \\
EA & $-1.02 \pm 0.37(3.0 \%)$ & $-0.145 \pm 0.108(1.3 \%)$ & $-0.086 \pm 0.050(4.0 \%)$ \\
SA & $-0.33 \pm 0.11(1.0 \%)$ & $-0.104 \pm 0.063(0.9 \%)$ & $-0.039 \pm 0.020(1.8 \%)$ \\
Total & $-3.23 \pm 1.11(9.2 \%)$ & $-0.388 \pm 0.263(3.5 \%)$ & $-1.33 \pm 0.44(2.8 \%)$ \\
\hline
\end{tabular}

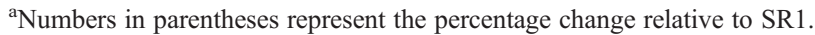

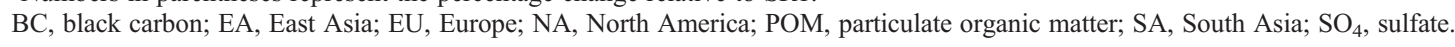

Table 5. Change of Global Annual Mean All-Sky Aerosol Direct Radiative Forcing ( $\mathrm{mW} \mathrm{m}{ }^{-2}$, mean \pm standard deviation) in Response to the 20\% Reduction of Anthropogenic Emissions in Four Source Regions as Derived From Analysis of SR1 and SR6 Runs of Eight Hemispheric Transport of Air Pollution Models ${ }^{\mathrm{a}}$

\begin{tabular}{|c|c|c|c|c|}
\hline Source Region & $\Delta \mathrm{DRF}_{\mathrm{SO} 4}$ & $\triangle \mathrm{DRF}_{\mathrm{POM}}$ & $\triangle \mathrm{DRF}_{\mathrm{BC}}$ & $\Delta \mathrm{DRF}_{\mathrm{SO} 4+\mathrm{POM}+\mathrm{BC}}$ \\
\hline \multicolumn{5}{|c|}{ All-sky TOA DRF $\left(\mathrm{mW} \mathrm{m}^{-2}\right)$} \\
\hline NA & $16.3 \pm 4.8(2.1 \%)$ & $1.4 \pm 1.0(0.5 \%)$ & $-3.1 \pm 1.7(1.3 \%)$ & $14.6 \pm 5.1(1.8 \%)$ \\
\hline EU & $25.5 \pm 8.8(3.4 \%)$ & $1.6 \pm 1.2(0.6 \%)$ & $-6.0 \pm 2.7(2.7 \%)$ & $21.1 \pm 9.7(2.6 \%)$ \\
\hline EA & $20.3 \pm 7.9(2.7 \%)$ & $3.1 \pm 2.3(1.1 \%)$ & $-9.7 \pm 6.4(4.3 \%)$ & $13.8 \pm 10.3(1.7 \%)$ \\
\hline SA & $6.9 \pm 2.1(0.9 \%)$ & $2.5 \pm 1.8(0.9 \%)$ & $-3.7 \pm 1.9(1.7 \%)$ & $5.7 \pm 2.7(0.7 \%)$ \\
\hline Four-region total & $69.0 \pm 22.5(9.0 \%)$ & $8.6 \pm 6.1(3.0 \%)$ & $-22.5 \pm 12.2(10.0 \%)$ & $55.1 \pm 26.0(6.7 \%)$ \\
\hline \multicolumn{5}{|c|}{ All-sky surface DRF $\left(\mathrm{mW} \mathrm{m}^{-2}\right)$} \\
\hline NA & $15.7 \pm 4.6(2.1 \%)$ & $1.9 \pm 1.4(0.5 \%)$ & $5.6 \pm 2.6(1.2 \%)$ & $23.2 \pm 5.2(1.5 \%)$ \\
\hline EU & $24.0 \pm 8.0(3.3 \%)$ & $2.4 \pm 1.8(0.6 \%)$ & $8.9 \pm 3.3(2.0 \%)$ & $35.3 \pm 6.9(2.2 \%)$ \\
\hline EA & $19.8 \pm 7.6(2.8 \%)$ & $4.5 \pm 3.4(1.1 \%)$ & $16.7 \pm 9.3(3.8 \%)$ & $41.0 \pm 12.0(2.6 \%)$ \\
\hline SA & $6.9 \pm 2.1(1.0 \%)$ & $3.6 \pm 2.5(0.9 \%)$ & $8.3 \pm 3.9(1.9 \%)$ & $18.8 \pm 4.9(1.2 \%)$ \\
\hline Four-region total & $66.4 \pm 21.2(9.1 \%)$ & $12.4 \pm 8.7(3.1 \%)$ & $39.5 \pm 17.7(8.9 \%)$ & $118.3 \pm 25.6(7.5 \%)$ \\
\hline
\end{tabular}

${ }^{a}$ Numbers in parentheses indicate a percentage of change with respect to SR1. BC, black carbon; DRF, direct radiative forcing; EA, East Asia; EU, Europe; NA, North America; POM, particulate organic matter; SA, South Asia; $\mathrm{SO}_{4}$, sulfate; TOA, top of atmosphere. 
Table 6. Global Annual Average Top of Atmosphere All-Sky Forcing Efficiency Relative to Emissions From the Source Regions $\left(\mathrm{mW} \mathrm{m}^{-2}\right.$ per Tg) as derived from Seven Hemispheric Transport of Air Pollution Models ${ }^{\mathrm{a}}$

\begin{tabular}{lccc}
\hline Source Region & $\mathrm{SO}_{4}$ & $\mathrm{POM}$ & $\mathrm{BC}$ \\
\hline NA & $-3.9 \pm 0.8$ & $-4.4 \pm 1.7$ & $27.3 \pm 15.3$ \\
EU & $-3.9 \pm 0.7$ & $-4.3 \pm 1.7$ & $37.4 \pm 19.3$ \\
EA & $-2.9 \pm 0.8$ & $-3.7 \pm 1.8$ & $28.4 \pm 20.4$ \\
SA & $-3.9 \pm 1.0$ & $-4.1 \pm 1.9$ & $25.3 \pm 14.6$ \\
Total & $-3.5 \pm 0.8$ & $-4.0 \pm 1.7$ & $29.5 \pm 18.1$ \\
\hline
\end{tabular}

${ }^{a}$ The forcing efficiency for sulfate $\left(\mathrm{SO}_{4}\right)$ and particular organic matter (POM) is calculated with respect to $\mathrm{SO}_{2}$ and primary POM emissions, although some models with fully coupled chemistry include changes of $\mathrm{SO}_{4}$ resulting from the reductions of other emissions and a fraction of POM is secondary aerosol produced from a variety of volatile organic carbon. Emissions from individual models are used. BC, black carbon; EA, East Asia; EU, Europe; NA, North America; SA, South Asia.

that for $\mathrm{SO}_{4}$ and POM. Despite wide model differences in the absolute value of forcing efficiency, several regional dependences appear to be rather robust among the models, as shown in Figures 7 and 8. Also shown in Figures 7 and 8 are changes of AOD normalized by regional emissions.
Figure 7 shows that all eight models consistently yield a smaller sulfate forcing efficiency for EA emissions than for EU emissions, which is consistent with the oxidant limitation in EA that reduces the efficiency of the $\mathrm{SO}_{2}$-to-sulfate transformation [Koch et al., 2007]. As shown in Figure 8, the models except Interaction of Chemistry and Aerosol (INCA) also consistently give the largest BC forcing efficiency for EU emissions. Not all the regional differences in forcing efficiency are consistent with those in the AOD change per emissions, presumably because some models differ from others in the simulated geographical distributions of AOD in response to regional emission reduction, and the NDRF depends on region. These results may have important implications for regional emission controls and their influences on global climate.

\subsection{Spatial Extents of the Aerosol Optical Depth and Direct Radiative Forcing Response and the Role of Intercontinental Transport}

[24] The spatial extents of the AOD and DRF changes due to the reduction of regional emissions and the role of aerosol ICT are revealed by differencing the SR6 and SR1

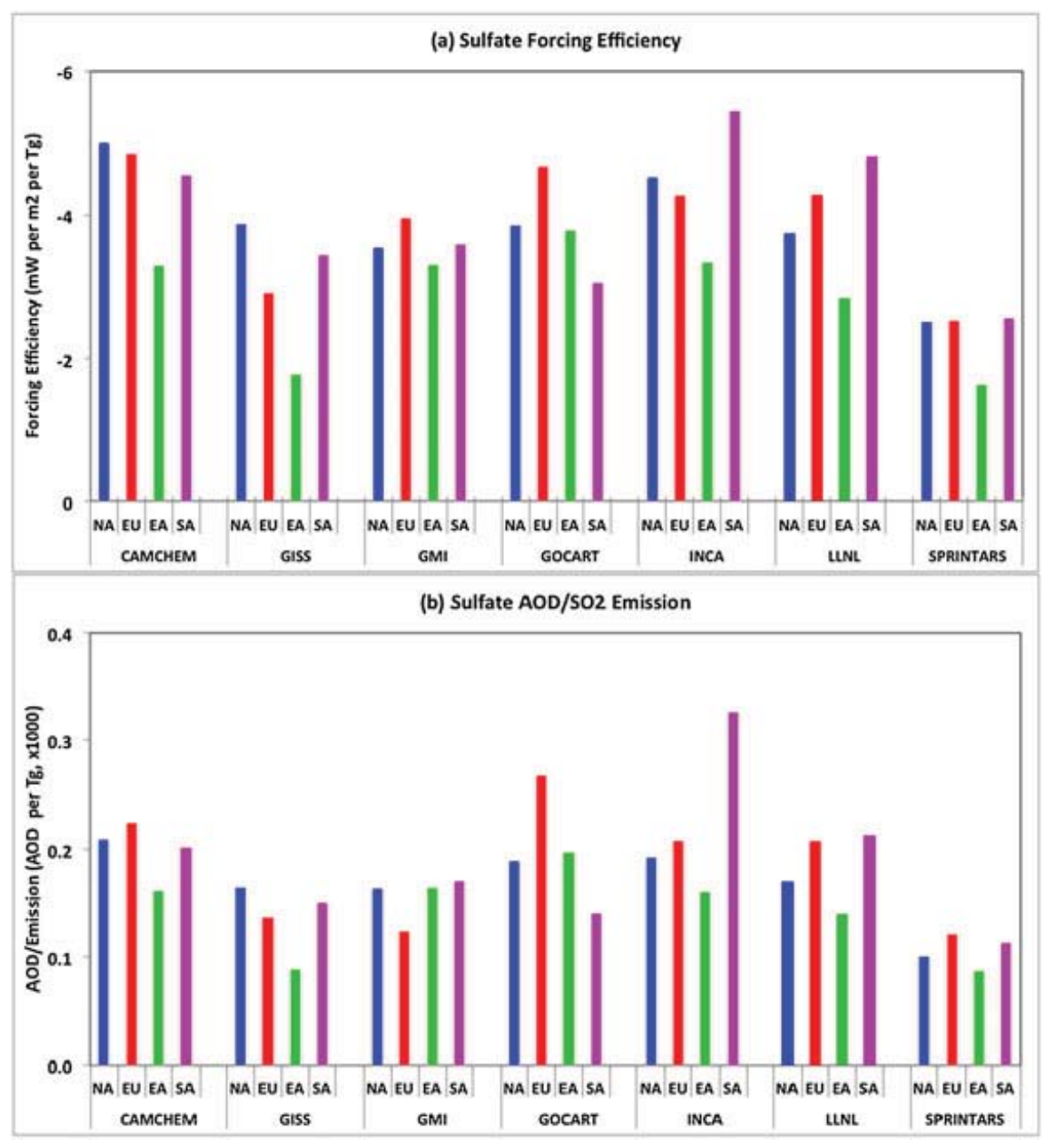

Figure 7. Global annual mean (a) forcing efficiency $\left(\mathrm{mW} \mathrm{m}^{-2}\right.$ per $\mathrm{Tg}$ ) and (b) AOD/emission (AOD per $\mathrm{Tg}, \times 1000$ ) attributed to $20 \%$ anthropogenic emissions in individual source regions (denoted as NA, EU, EA, and SA) as simulated by seven HTAP models. 


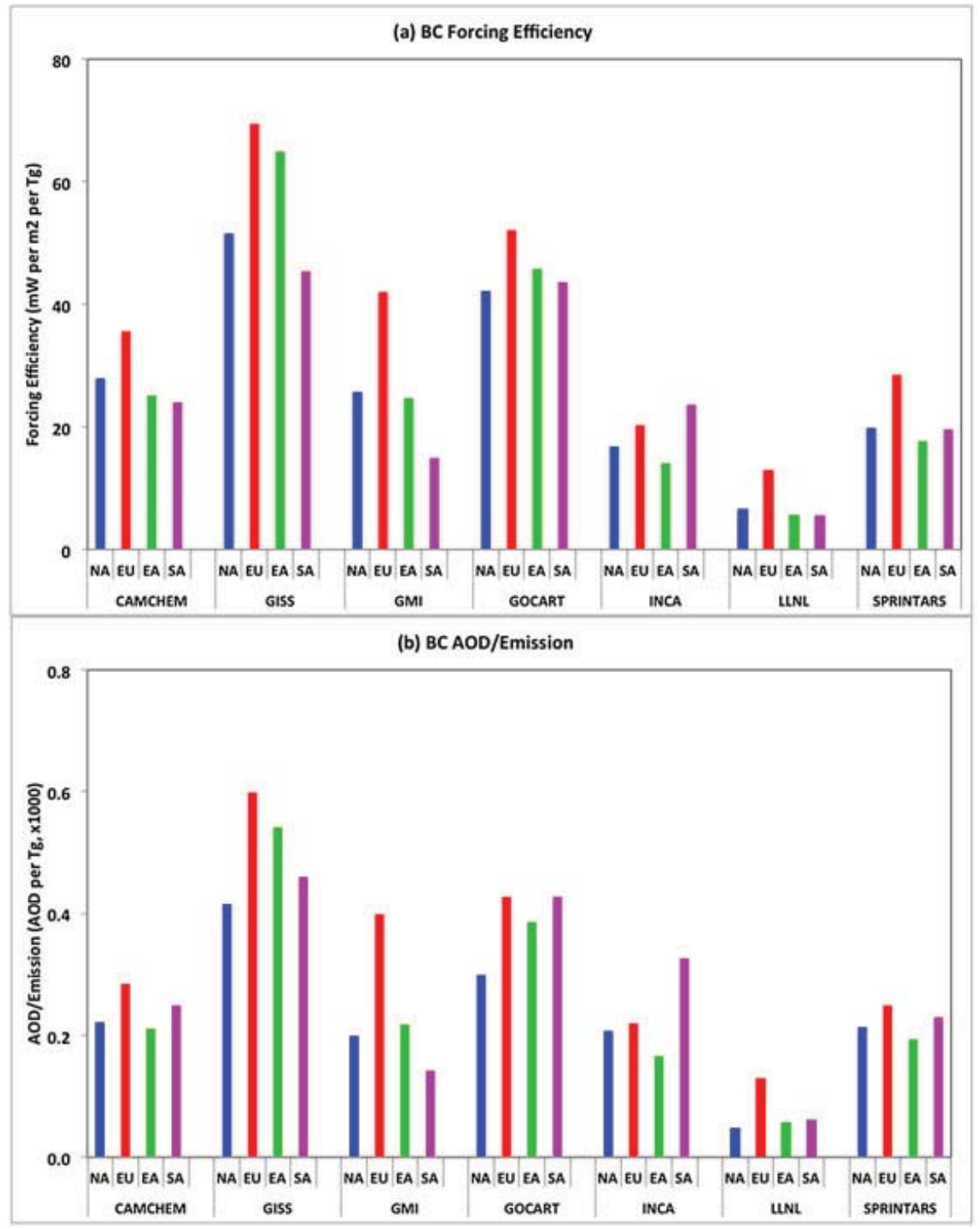

Figure 8. Same as Figure 7 but for BC.

experiments. Figure 9 shows the eight-model annual average changes of AOD and all-sky DRF by the external mixture of $\mathrm{SO}_{4}$, POM, and $\mathrm{BC}$, resulting from the $20 \%$ reduction of anthropogenic emissions over the four regions. Corresponding relative changes are shown in Figure 10. Clearly, emissions from NA, EU, and EA exert significant DRF on intercontinental and even hemispheric scales. Emissions from SA have relatively small impacts mainly over the Indian Ocean and the tropical Pacific. The influences of regional emission reduction on AOD and DRF also depend on season. As an example, Figures 11 and 12 show the absolute and relative changes of the seasonal mean all-sky surface DRF between SR1 and SR6. Similar seasonal variations occur for AOD, all-sky DRF at TOA, and clear-sky DRF (as shown in Figures S3-S6). For all regions, the 20\% reduction of emissions in each region decreases the direct forcing (i.e., less negative) by a larger amount and over more extensive areas in summer and spring than in winter and fall.

[25] We calculate the RAIR for AOD and DRF for nine individual models and then obtain multimodel average and standard deviations. In this section, we include ECHAM5 results. RAIR would be less sensitive to water optical depth than AOD is, because it is a ratio of import to the sum of import and domestic production, and the water contribution in the imported and domestic aerosol is partly canceled out. If sulfate aerosol via ICT is not significantly different from domestic aerosols in the vertical distribution, then RAIR for ambient aerosol is similar to that for dry aerosol. Because we have used the same NDRF to convert AOD to DRF, RAIR values for DRF are almost identical to that of AOD. As discussed earlier, however, RAIR values for BC all-sky TOA DRF should have been underestimated in this study. We show RAIR for AOD in Figure 13. Table 7 lists the nine-model statistics of RAIR (average \pm one standard deviation). Clearly, values of RAIR depend on both region and component, as suggested. For all regions and components, the import from ICT is significant, but local emissions remain the main contributor, as suggested by a large majority of the models [except that RAIR is slightly more than $50 \%$ for POM in NA by INCA and for BC in NA by 


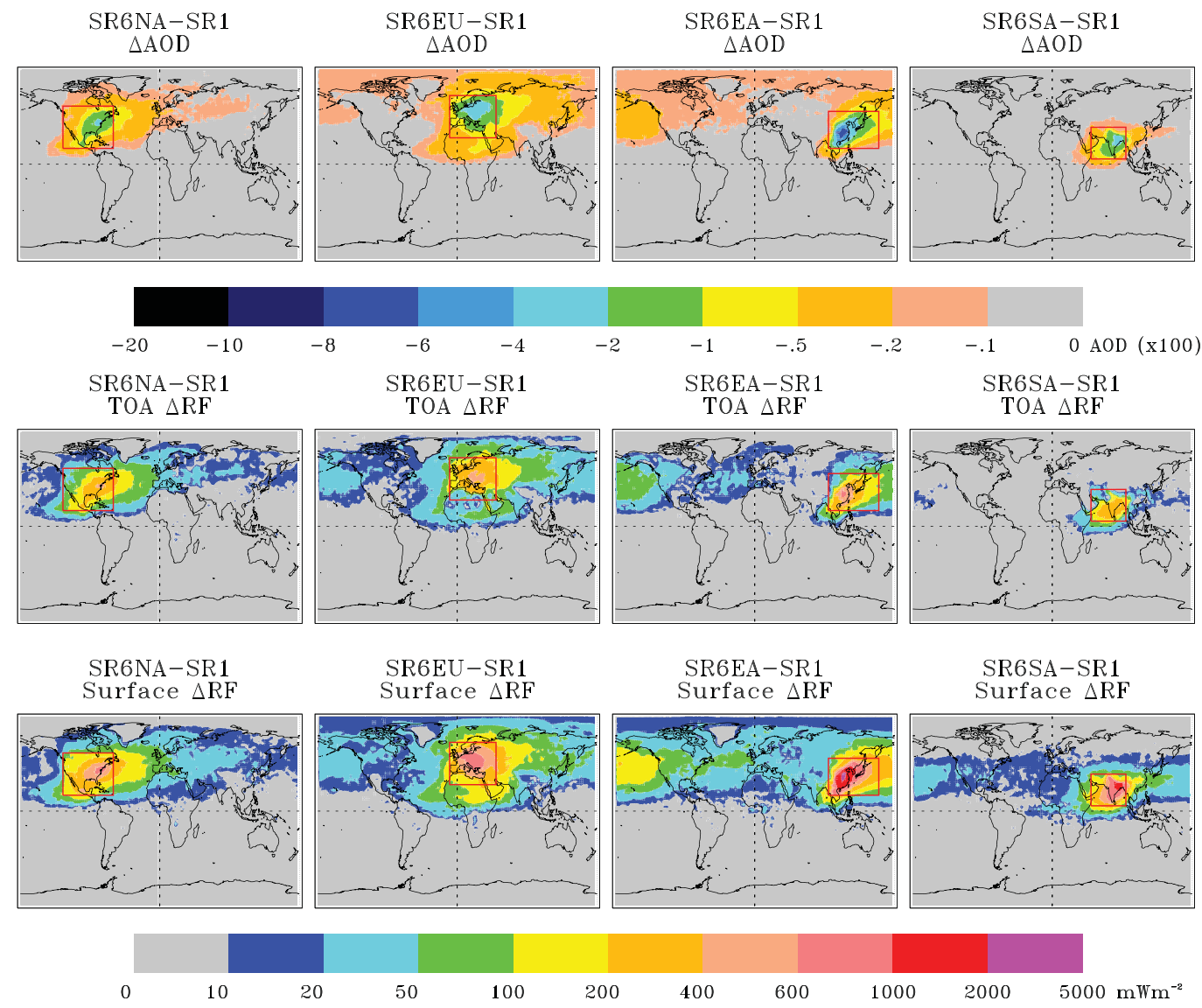

Figure 9. Annual average AOD $\left(\times 100\right.$, top panel) and DRF $\left(\mathrm{mW} \mathrm{m}^{-2}\right)$ at the top of atmosphere $(\mathrm{TOA})$ (middle panel) and at the surface (bottom panel) in all-sky conditions resulting from $20 \%$ reductions of anthropogenic emissions from each region (mean of eight models). A positive value for DRF represents the reduced aerosol direct radiative forcing resulting from the reduction of emissions. Red boxes show each of the four source regions. Individual aerosol components are assumed to be mixed externally.

HadGEM2 and Goddard Institute for Space Studies, Physical Understanding of Composition-Climate Interactions and Impacts model (GISS PUCCINI)]. The nine-model average yields RAIR ranging from $11 \pm 5 \%$ to $31 \pm 9 \%$. SA is most influenced by the import of sulfate aerosol $(\mathrm{RAIR}=30 \pm 9 \%)$, and NA is most influenced by the import of $\mathrm{BC}(\mathrm{RAIR}=28 \pm 18 \%$ ), followed by $\mathrm{POM}(\mathrm{RAIR}=21$ $\pm 18 \%)$. These rankings also reflect the strength of local emissions relative to world emissions, as discussed in section 2. Interestingly, nine-model average RAIR values for sulfate $(15-31 \%)$ are consistently smaller than that for aerosol column loading (i.e., 24-37\%) [see Table 4.4 in HTAP, 2010]. For POM, RAIR values (17-21\%) in NA and EU are also somewhat smaller than the corresponding RAIR values (21-23\%) for the column mass loading. These differences probably stem from transported sulfate and POM aerosols experiencing lower relative humidity at high altitude (resulting in lower optical depth) than local aerosols, which generally remain at lower altitudes.

[26] Clearly shown in Figure 13 and Table 7 is large intermodel variability. For all components in NA and EU, the standard deviation of RAIR is $60 \%$ to $80 \%$ of the ninemodel average. In comparison, the model variability in EA and SA is smaller, with the standard deviation being $30 \%$ to $47 \%$ of the nine-model average. The intermodel variability can only be explained partly by differences in emissions (Figure 2). Differences in aerosol chemistry, transport height, wind speed, and removal processes among the models should contribute significantly to the variability of RAIR. One interesting feature shown in Figure 13 is the difference in RAIR between Global Modeling Initiative (GMI) and GOCART models for POM and BC. Except in SA, the GMI RAIR value is significantly smaller than corresponding value of GOCART. As shown in Table S1, the two models use similar emission databases, aerosol chemistry, meteorological fields, dry deposition schemes, and aerosol optical properties. But the two models differ partly in the parameterization of wet removal processes. Although GOCART does not account for rainout and washout by convective clouds, GMI does. It is most likely that this difference in wet removal is a major reason for the difference in RAIR. Fully understanding the model variability shown in Figure 13 needs substantial efforts in the future on testing a variety of processes in a single modeling framework.

[27] Figures 14 and 15 shows absolute and relative contributions of individual source regions to AOD changes in the receptor region. The response of annual mean AOD and allsky DRF in receptor regions to a $20 \%$ reduction of 


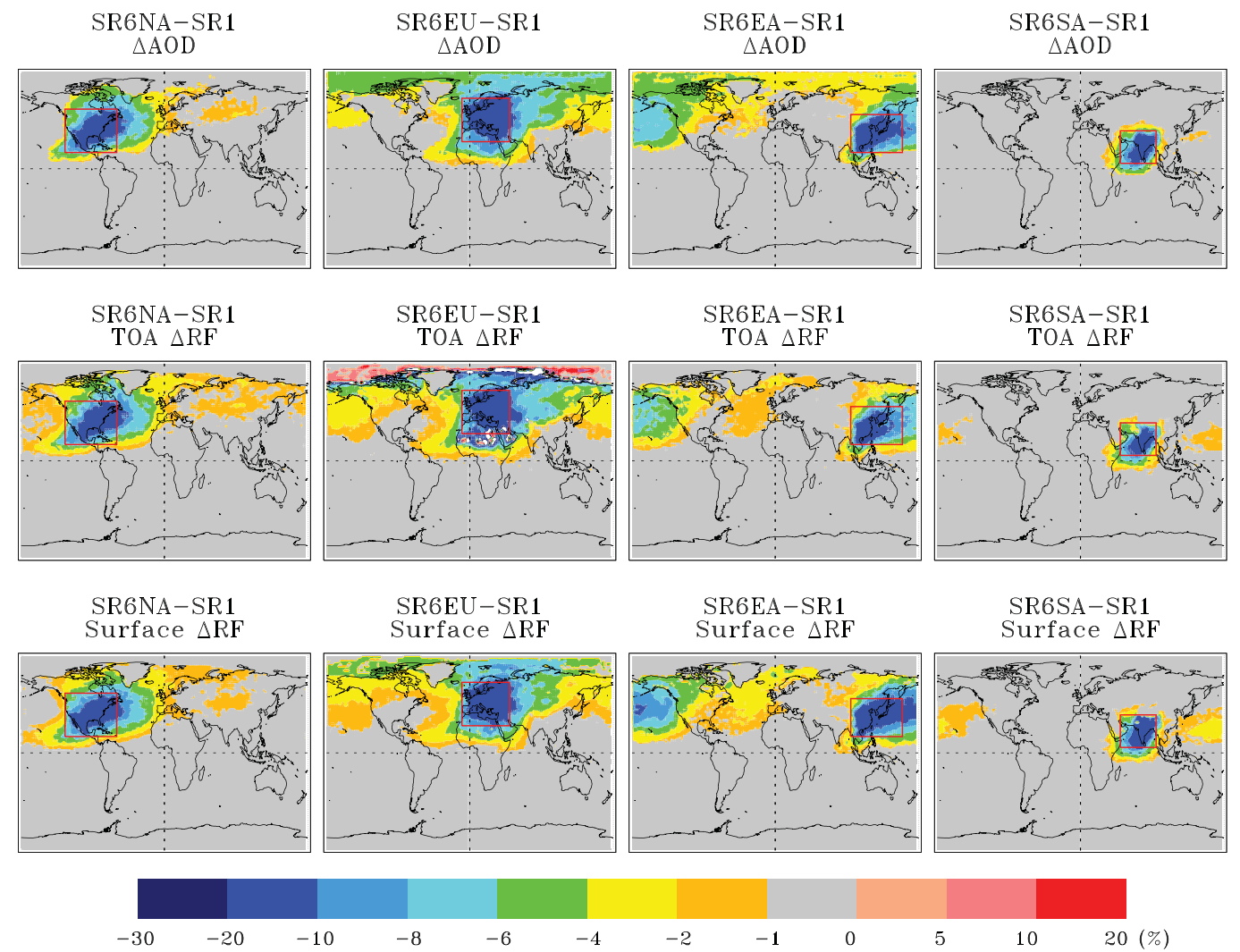

Figure 10. Same as Figure 9, but for relative change (\%).

anthropogenic emissions in the four source regions is detailed in Table S2. Not surprisingly, the influences on AOD and DRF from the reduction of domestic emissions is about an order of magnitude larger than from any foreign source region. Foreign source regions also differ in contributing to the total import for a specific receptor region. The ICT of EA emissions accounts for the largest fraction of total import in NA, i.e., $50 \%, 50 \%$, and $66 \%$ for $\mathrm{SO}_{4}$, $\mathrm{POM}$, and $\mathrm{BC}$, respectively. The NA emissions make the largest contribution $(\sim 50 \%)$ to the total import of $\mathrm{SO}_{4}$ and POM into EU. For $\mathrm{BC}$ aerosols imported to EU, on the other hand, the EA contribution of $42 \%$ exceeds the NA contribution of $33 \%$, presumably because of much higher BC emissions in EA. The imported BC to EA comes mostly (69\%) from SA, followed by those from EU (e.g., 25\%). For the import of $\mathrm{SO}_{4}$ to EA, SA and EU emissions make quite comparable contributions, which is a factor of 3 to 4 larger than the import of NA emissions. More than $80 \%$ of POM import to EA comes from SA, presumably due to the geographical proximity and high POM emissions in SA. In SA, the imported $\mathrm{SO}_{4}$ is significant, with RAIR of $31 \%$, of which $66 \%$ comes from EU, followed by $28 \%$ from EA. For BC aerosols in SA, the import from EA and EU emissions contributes comparably, e.g., $50 \%$ and $44 \%$, respectively

[28] Our multimodel estimates of the relative contributions of local emissions and ICT import are generally consistent with results in literature. In NA, we estimate that local emissions account for $82 \%, 75 \%$, and $64 \%$ of AOD for sulfate, $\mathrm{POM}$, and $\mathrm{BC}$, respectively (Figure 15). In comparison, Leibensperger et al. [2012a] use the GEOS-Chem model to estimate that anthropogenic emissions in the United States contribute about $67 \%, 69 \%$, and $64 \%$ of AOD for sulfate, $\mathrm{POM}$, and $\mathrm{BC}$, respectively. The difference in sulfate AOD contributed by local emissions between this study and Leibensperger et al. [2012a] are consistent with the $\mathrm{SO}_{2}$ emission differences. Although in this study the $\mathrm{SO}_{2}$ emission from NA accounts for 15\% (13.6-16.1\%, depending on models) of global emissions, corresponding percentage in Leibensperger et al. [2012a] is only 8\%. The BC fractional contributions from different source regions as estimated in this study also agree well with a model estimate [Reddy and Boucher, 2007, hereinafter RB09]. RB09 estimated that over NA, emissions from EA and SA contribute to $18 \%$ and $6 \%$ of the total $\mathrm{BC}$ burden, respectively, which are somewhat smaller than our corresponding estimate of $23 \%$ and $8 \%$. The contribution of NA emissions to $\mathrm{BC}$ burden in EU was estimated at 5\% in RB09, which is also somewhat smaller than our estimated 8\%. RB09 estimated that the local $\mathrm{BC}$ emissions over SA and EA accounts for more than $80 \%$ of the BC burden, which agrees well with our estimate of $82 \%$ and $84 \%$. These comparisons show how the estimated significance of ICT import in this study agrees broadly with results in the literature, as these studies have defined source regions somewhat differently.

\section{Conclusions and Discussion}

[29] We have assessed impacts of a $20 \%$ reduction of anthropogenic emissions in NA, EU, EA, and SA on the AOD by using results from 10 global chemical transport or general circulation models in the framework of HTAP. Impacts on aerosol DRF have also been estimated using 


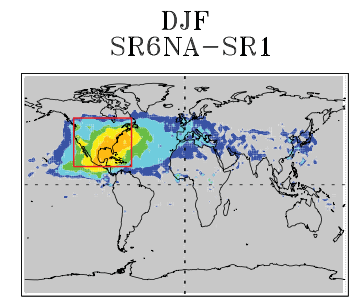

SR6EU-SR1

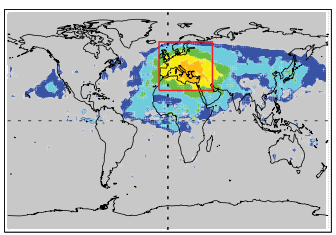

SR6EA-SR1

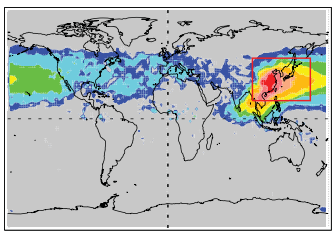

SR6SA-SR 1

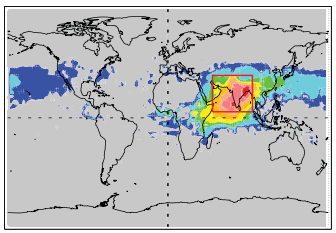

MAM SR6NA-SR 1

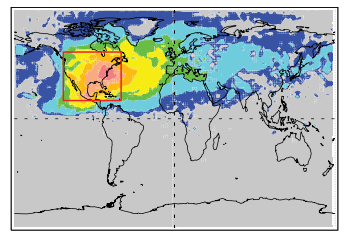

SR6EU-SR 1

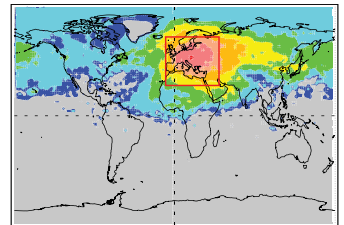

SR6EA-SR 1

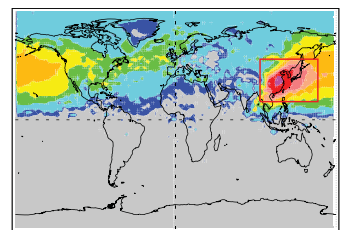

SR6SA-SR1

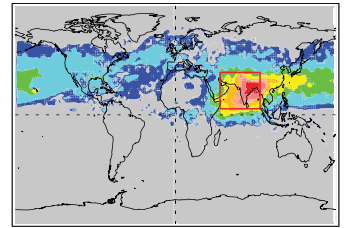

JJA SR6NA-SR1

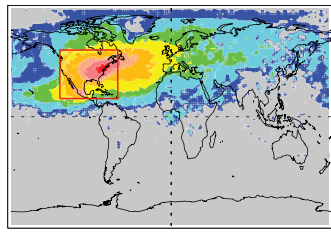

SR6EU-SR1

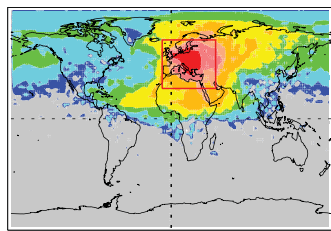

SR6EA-SR1

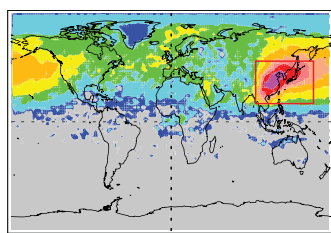

SR6SA-SR 1

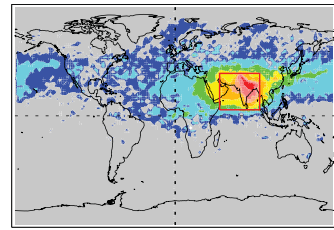

SON SR6NA-SR1

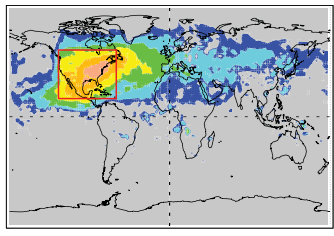

SR6EU-SR1

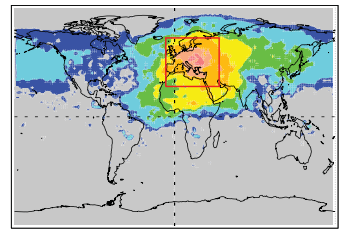

SR6EA-SR1

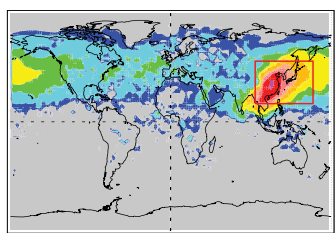

SR6SA-SR1

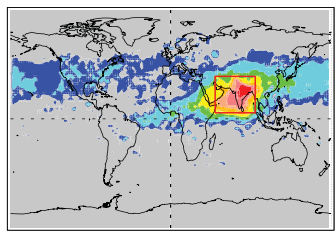

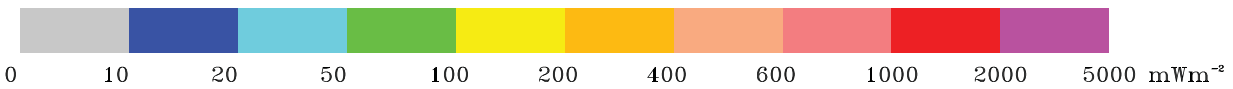

Figure 11. Absolute changes $\left(\mathrm{mW} \mathrm{m}^{-2}\right)$ of all-sky DRF at surface (SR6-SR1) due to $20 \%$ reduction of regional anthropogenic emissions derived from eight HTAP models.

the AOD results from individual models and the AODNDRF from the GOCART model. On the basis of the multimodel average, a $20 \%$ reduction of anthropogenic emissions in the four regions combined lowers the global mean AOD (all-sky TOA DRF) by $9.2 \%(9.0 \%), 3.5 \%(3.0 \%)$, and $9.4 \%(10.0 \%)$ for sulfate, organic matter, and $\mathrm{BC}$ aerosol, respectively. Global annual average TOA all-sky direct forcing efficiency relative to particle or gaseous precursor emissions from the four regions (expressed as multimodel mean \pm one standard deviation) is $-3.5 \pm 0.8,-4.0 \pm 1.7$, and $29.5 \pm 18.1 \mathrm{~mW} \mathrm{~m}^{-2}$ per $\mathrm{Tg}$ for sulfate (relative to $\mathrm{SO}_{2}$ ), POM, and $\mathrm{BC}$, respectively. Despite the considerable model-to-model differences in the magnitude of the forcing efficiency, a large majority of models appear to consistently give a lower sulfate forcing efficiency for $\mathrm{SO}_{2}$ emissions from EA than that from EU, and the largest BC forcing efficiency for the EU emissions. These results may have important implications for emission-control strategies for climate change, which need to be assessed by accounting for cost and feasibility. Such implications also need to be further explored by taking into account a variety of aerosol impacts on climate by modifying cloud microphysics, atmospheric circulations, and snow albedo. The air-quality implication of any emission control should also be considered.

[30] Our multimodel simulations of $\mathrm{S} / \mathrm{R}$ relationships show that the impacts of the regional emission reductions are not confined to the region itself because of aerosol ICT. On an annual basis, ICT accounts for $11 \pm 5 \%$ (multimodel mean \pm standard deviation) to $31 \pm 9 \%$ of AOD and DRF in a receptor region, compared to the influence of both regional emissions and ICT, depending on regions and species. For sulfate AOD, SA is most influenced by import of sulfate aerosol mainly from EU with RAIR of $31 \pm 9 \%$. For $\mathrm{BC}$ AOD, NA is most influenced by import of $\mathrm{BC}$ aerosol from mainly EA (RAIR $=28 \pm 18 \%$ ). Given that $\mathrm{BC}$ deposition may accelerate the melting of snow in the Sierra Nevada and cause water supply shortage in summer in the western United States [Hadley et al., 2010], the region may benefit from a future control of BC emissions in Asia.

[31] The results of this study have several limitations. The relative role of ICT versus domestic emissions has been assessed at continental or subcontinental scales. However, the aerosol DRF efficiency differs considerably from region to region [Henze et al., 2012]. Future assessments could be 

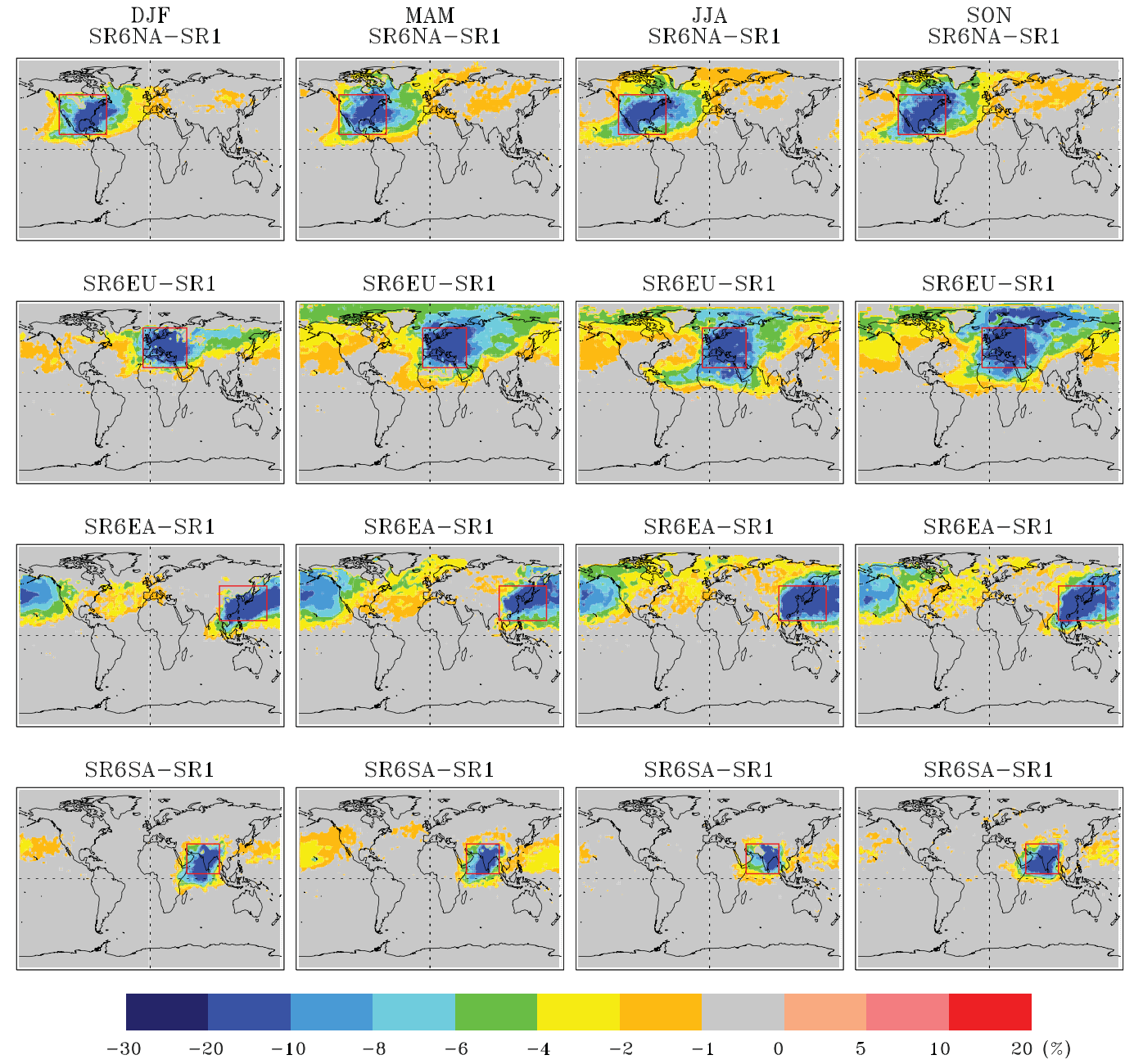

Figure 12. Same as Figure 11, but for relative changes (\%).
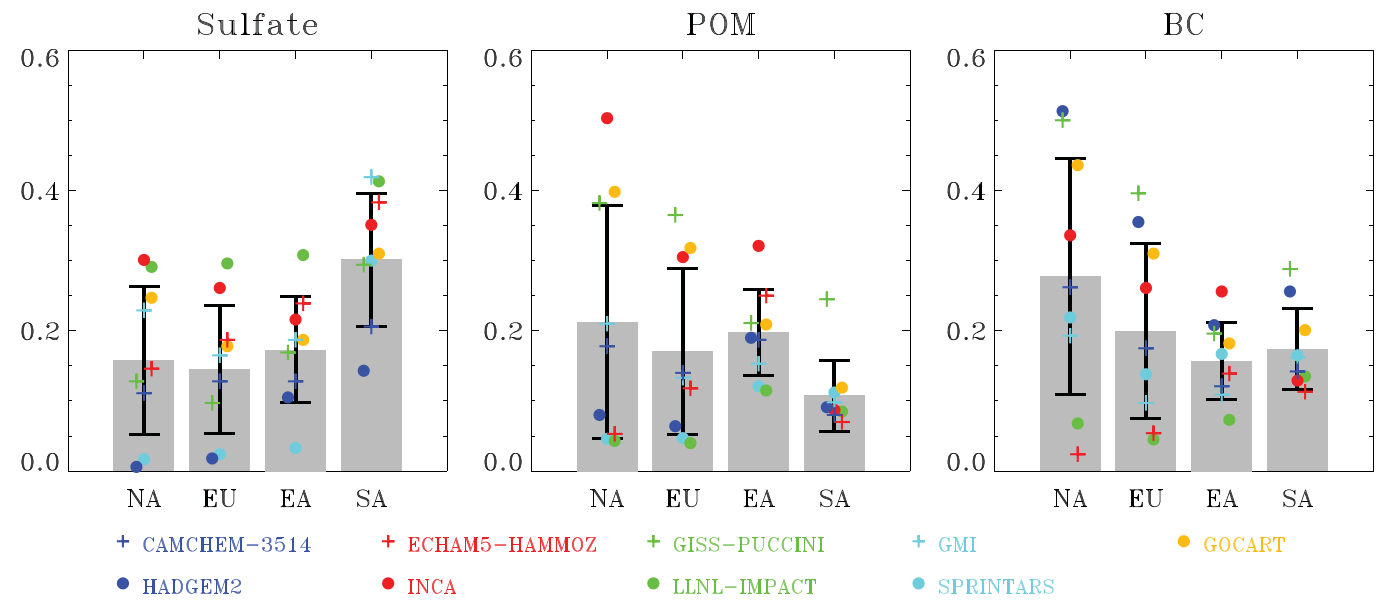

Figure 13. Relative annual intercontinental response (RAIR) for AOD in four receptor regions, by chemical component derived from nine models. The gray box and error bar indicate nine-model average and standard deviation, respectively. RAIR values for TOA and surface DRF are almost identical to that for AOD and hence are not shown here. 
Table 7. Nine-Model Average ( \pm standard deviation) of Relative Annual Intercontinental Response for Sulfate, Particulate Organic Matter, and Black Carbon in the Four Regions ${ }^{\mathrm{a}}$

\begin{tabular}{lcccc}
\hline & NA & EU & EA & SA \\
\hline Sulfate & $16 \pm 11 \%$ & $15 \pm 10 \%$ & $18 \pm 8 \%$ & $31 \pm 9 \%$ \\
POM & $21 \pm 18 \%$ & $17 \pm 13 \%$ & $20 \pm 6 \%$ & $11 \pm 5 \%$ \\
BC & $28 \pm 18 \%$ & $20 \pm 13 \%$ & $16 \pm 6 \%$ & $18 \pm 6 \%$
\end{tabular}

${ }^{\mathrm{a} B C}$, black carbon; EA, East Asia; EU, Europe; NA, North America; POM, particulate organic matter; SA, South Asia.
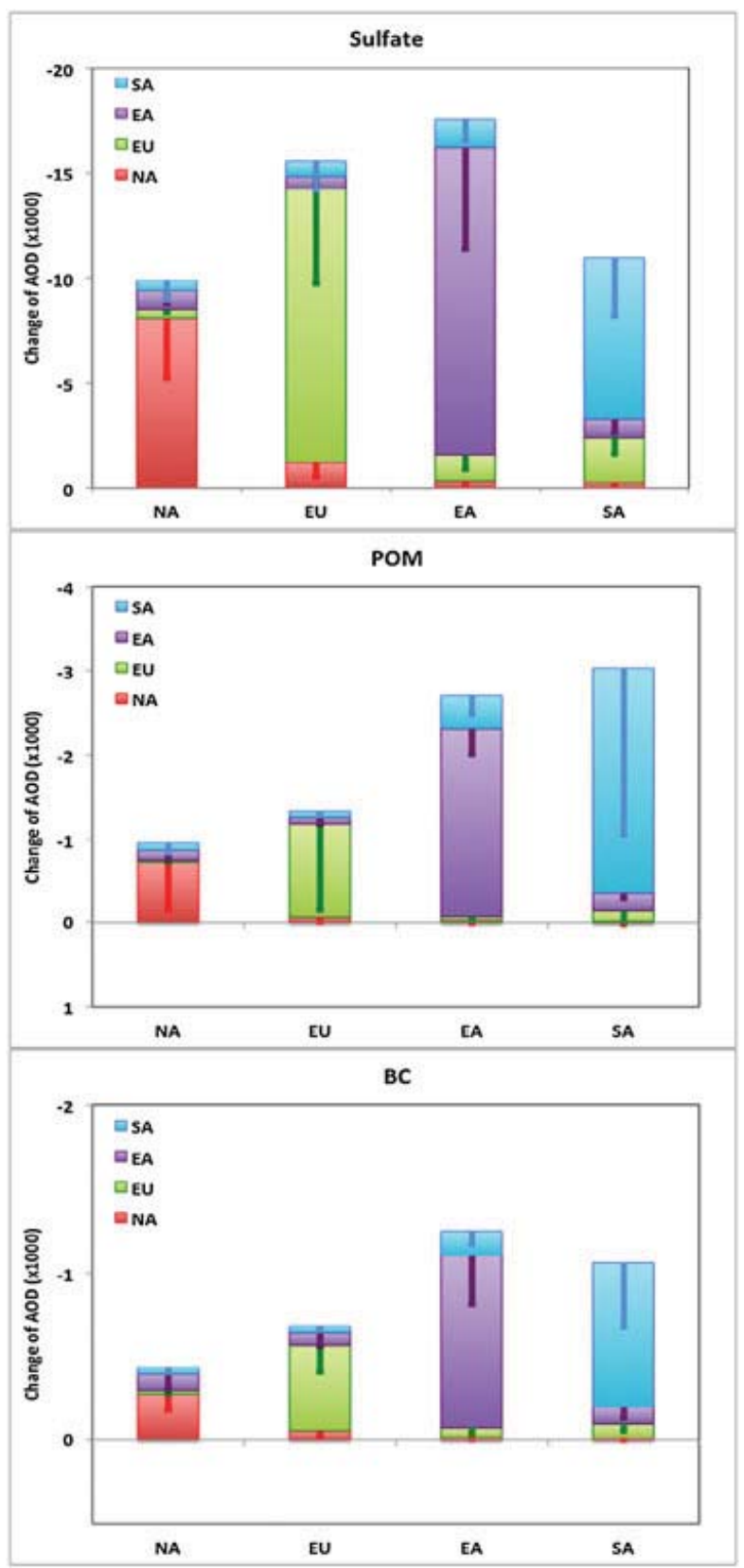

Figure 14. Contributions of individual source regions (identified with different colors) to AOD changes in the receptor regions ( $x$ axis), with error bar indicating standard deviation of eight models.

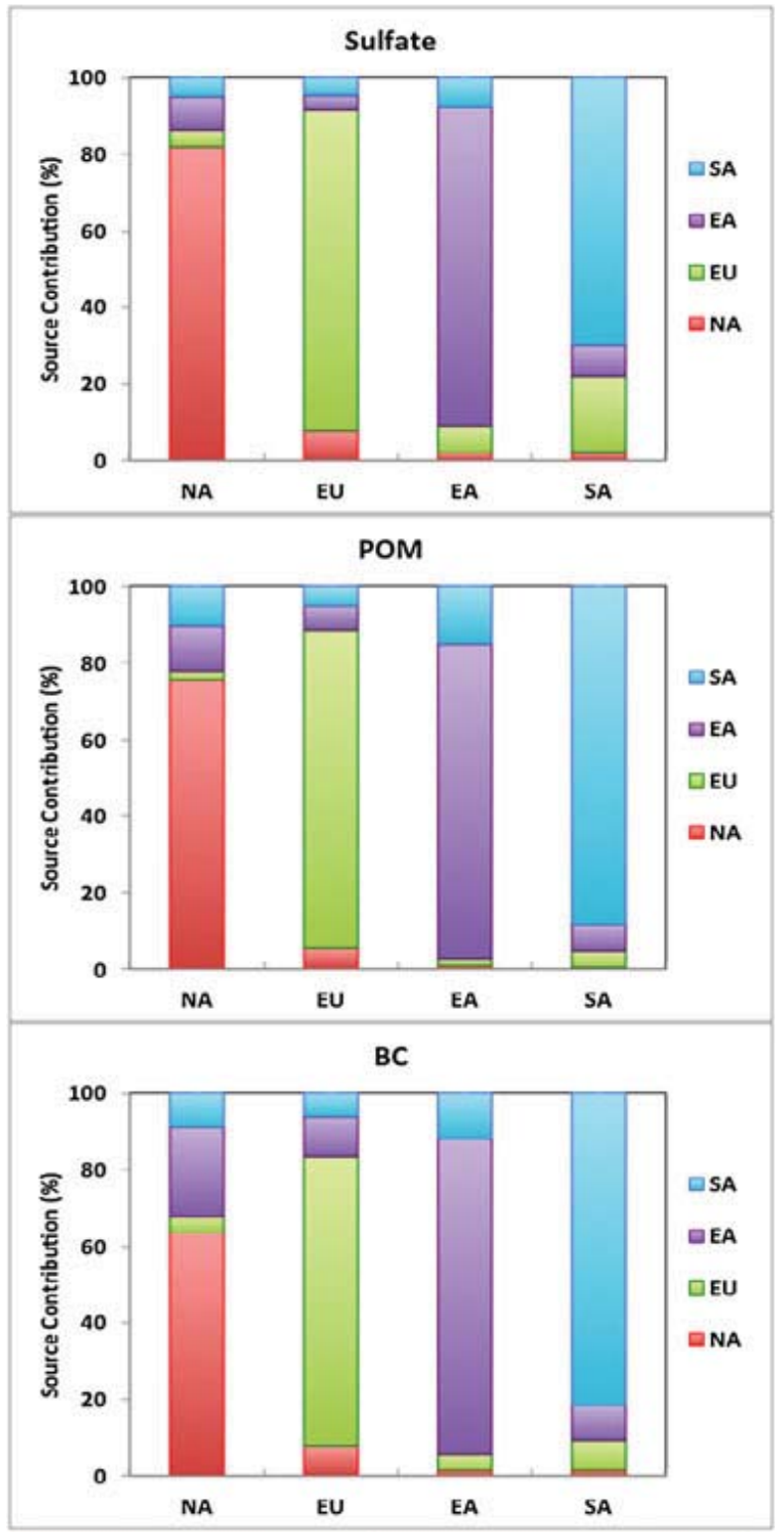

Figure 15. Percentage contributions of individual source regions to AOD changes in the receptor regions ( $\mathrm{x}$ axis) based on the eight-model average.

conducted at finer scale by defining more emission regions. For example, EA emissions are expected to influence the western part of NA more than the eastern part. A separation of the current NA region into western and eastern sections can offer more insights. This study has used global models with a horizontal resolution of more than $100 \mathrm{~km}$. Given that the aerosol ICT and its influences involve a wide span of scales, it is necessary to develop modeling systems that link the local, regional, intercontinental, and global scales. In this study, assessments of AOD and its changes in response to the emission reduction could be more robust than that of DRF, because the DRF has been estimated using AOD from individual models and a NDRF from a single model. This simplification may have understated the model diversity in DRF. As discussed earlier, the implicit assumption that the NDRF does not depend on aerosol vertical 
distribution could have underestimated the role of BC ICT on DRF. Future HTAP experiments should request DRF results from individual models. This analysis has considered only aerosol DRF. Future assessments should consider impacts of aerosols on snow albedo and cloud properties, although some modeling studies suggest that the global aerosol RF is predominated by the DRF [Bauer and Menon, 2012]. This study also focuses on aerosol DRF and does not address the climate response to the forcing. As discussed earlier, relationships between the spatial patterns of RF and climate response have not been unambiguously established. We believe that the regional patterns of forcing and ICT likely have some influence for regional climate, although that influence is uncertain. A robust assessment of the influence requires a better quantification of the relationship between forcing in various locations and different aspects of climate response.

[32] The multimodel assessment in this study shows large differences between models in the impacts of emission reductions and the role of ICT, which highlights a need for improving models and developing observational databases for evaluating and constraining models. From the perspective of model improvements, efforts should focus on not only emission inventories [Textor et al., 2007], but also a variety of atmospheric processes that determine the atmospheric evolution of aerosols, such as parameterization of aerosol removal processes [Prospero et al., 2010]. Quantifying anthropogenic AOD distributions from satellite measurements remains challenging, in particular over land. Current estimates of anthropogenic AOD based on total AOD and fine-model fraction measurements from MODIS are feasible only over the ocean and are subject to large uncertainties [Yu et al., 2009; Bellouin et al., 2005, 2008]. Such an estimate would be better constrained by a synergistic use of aerosol microphysical measurements as provided by other satellite sensors. Emerging satellite observations of aerosols above clouds [Waquet et al., 2009; Torres et al., 2012; Yu et al., 2012 b] in recent years could provide additional constraints for model simulations. Substantial effort is needed in the future to fully explotre the potential offered by existing satellites and to develop new and enhanced satellite emissions [Yu et al., 2013].

[33] Acknowledgments. H.Y. was supported by NASA grant NNX11AH66G, managed by Richard Eckman. M.C. and H.B. were supported by NASA Modeling, Analysis, and Prediction program managed by David Considine. C.S.A. and D.B. were supported by the U.S. Department of Energy (BER) at LLNL under contract DE-AC52-07NA27344. N.B. thanks Shekar Reddy, formerly with the Met Office Hadley Centre, for carrying out the HadGEM2 simulations. We are grateful to many colleagues, including Frank Dentener and Bill Collins, for helpful comments. The HTAP experiments used in this study were organized by Martin Schultz, Arlene Fiore, Kees Cuvelier, Frank Dentener, Christiane Textor, Terry Keating, and Andre Zuber. We are grateful to Daven Henze and three anonymous reviewers for their constructive comments and suggestions that have significantly improved the quality of paper.

\section{References}

Albrecht, B. (1989), Aerosols, cloud microphysics, and fractional cloudiness, Science, 245, 1227-1230.

Anderson, T. L., et al. (2005), An "A-Train" strategy for quantifying direct aerosol forcing of climate, Bull. Am. Met. Soc., 86, 1795-1809.

Bates, T. S., et al. (2001), Regional physical and chemical properties of the marine boundary layer aerosol across the Atlantic during Aerosols99: An overview, J. Geophys. Res., 106(D18), 20,767-20,782.
Bauer, S. E., and S. Menon (2012), Aerosol direct, indirect, semi-direct, and surface albedo effects from sector contributions based on the IPCC AR5 emissions for preindustrial and present-day conditions, J. Geophys. Res., 117, D01206, doi:10.1029/2011JD016816.

Bellouin, N., O. Boucher, J. Haywood, and M. S. Reddy (2005), Global estimate of aerosol direct radiative forcing from satellite measurements, $\mathrm{Na}$ ture, 438, 1138-1141, doi:10.1038/nature04348.

Bellouin, N., A. Jones, J. Haywood, and S. A. Christopher (2008), Updated estimate of aerosol direct radiative forcing from satellite observations and comparison against the Hadley Centre climate model, J. Geophys. Res., 113, D10205, doi:10.1029/2007JD009385.

Bellouin, N., J. Rae, A. Jones, C. Johnson, J. Haywood, and O. Boucher (2011), Aerosol forcing in the Climate Model Intercomparison Project (CMIP5) simulations by HadGEM2-ES and the role of ammonium nitrate, J. Geophys. Res., 116, D20206, doi:10.1029/2011JD016074.

Bian, H., M. Chin, J. M. Rodriguez, H. Yu, J. E. Penner, and S. Strahan (2009), Sensitivity of aerosol optical thickness and aerosol direct radiative effect to relative humidity, Atmos. Chem. Phys., 9, 2375-2386, doi:10.5194/acp-9-2375-2009.

Bollasina, M. A., Ming, Y., and Ramaswamy, V. (2011), Anthropogenic aerosols and the weakening of the South Asian summer monsoon, Science, 334, 502-505.

Cappa, C. D., et al. (2012), Radiative absorption enhancements due to the mixture state of atmospheric black carbon, Science, 337, 1078-1081.

Chin, M., et al. (2002), Tropospheric aerosol optical thickness from the GOCART model and comparisons with satellite and sun photometer measurements, J. Atmos., Sci., 59, 461-483.

Chin, M., T. Diehl, P. Ginoux, and W. Malm (2007), Intercontinental transport of pollution and dust aerosols: Implications for regional air quality, Atmos. Chem. Phys., 7, 5501-5517, doi:10.5194/acp-7-5501-2007.

Chin, M., T. Diehl, O. Dubovik, T. F. Eck, B. N. Holben, A. Sinyuk, and D. G. Streets (2009), Light absorption by pollution, dust and biomass burning aerosols: A global model study and evaluation with AERONET data. Ann. Geophys., 27, 3439-3464.

Chou, M. D., M. J. Suarez, C. H. Ho, M. M. H. Yan, and K. T. Lee (1998), Parameterizations for cloud overlapping and shortwave single-scattering properties in the Goddard GCM, J. Clim., 11, 201-214.

Chung, S. H., and J. H. Seinfeld (2002), Global distribution and climate forcing of carbonaceous aerosols, J. Geophys. Res., 107, 4407, doi:10.1029/2001JD001397.

Clarke, A., and V. Kapustin (2010), Hemispheric aerosol vertical profiles: Anthropogenic impacts on optical depth and cloud nuclei, Science, 329, 1488-1492.

Dentener, F., et al. (2006), Emissions of primary aerosol and precursor gases in the years 2000 and 1750 prescribed data-sets for AeroCom, Atmos. Chem. Phys., 6, 4321-4344.

Dirksen, R. J., K. F. Boersma, J. de Laat, P. Stammes, G. R. van der Werf, M. Val Martin, and H. M. Kelder (2009), An aerosol boomerang: Rapid around-the-world transport of smoke from the December 2006 Australian forest fires observed from space, J. Geophys. Res., 114, D21201, doi:10.1029/2009JD012360.

Emmons, L. K., et al. (2010), Description and evaluation of the Model for Ozone and Related chemical Tracers, version 4 (MOZART-4), Geosci. Model Dev., 3, 43-67.

Fiore, A. M., et al. (2009), Multimodel estimates of intercontinental sourcereceptor relationships for ozone pollution, J. Geophys. Res., 114, D04301, doi:10.1029/2008JD010816.

Fischer, E. V., D. A. Jaffe, N. A. Marley, J. S. Gaffney, and A. Marchany-Rivera (2010), Optical properties of aged Asian aerosols observed over the U.S. Pacific Northwest, J. Geophys. Res., 115, D20209, doi:10.1029/ 2010JD013943.

Forster, P., et al. (2007), Changes in atmospheric constituents and radiative forcing, in Climate Change 2007: The Physical Scientific Basis, Cambridge University Press, Cambridge, U. K.

Fry, M. M., et al. (2012), The influence of ozone precursor emissions from four world regions on tropospheric composition and radiative climate forcing, J. Geophys. Res., 117, D07306, doi:10.1029/2011JD017134.

Gunn, R., and B. B. Philips (1957), An experimental investigation of the effect of air pollution on the initiation of rain, J. Meteorol., 14, 272-280.

Hadley, O. L., V. Ramanathan, G. R. Carmichael, Y. Tang, C. E. Corrigan, G. C. Roberts, and G. S. Mauger (2007), Trans-Pacific transport of black carbon and fine aerosols (D $<2.5 \mu \mathrm{m})$ into North America, J. Geophys. Res., 112, D05309, doi:10.1029/2006JD007632.

Hadley, O. L., C. E. Corrigan, T. W. Kirchstetter, S. Cliff, and V. Ramanathan (2010), Measured black carbon deposition on the Sierra Nevada snow pack and implication for snow pack retreat. Atmos. Chem. Phys., 10, 7505-7513.

Hauglustaine, D. A., F. Hourdin, S. Walters, L. Jourdain, M.-A. Filiberti, J.-F. Larmarque, and E. A. Holland (2004), Interactive chemistry in the Laboratoire de Météorologie Dynamique general circulation model: 


\section{YU ET AL.: AEROSOL INTERCONTINENTAL TRANSPORT}

Description and background tropospheric chemistry evaluation, J. Geophys. Res., 109, D04314, doi:10.1029/3JD003957.

Heald, C. L., et al. (2006), Transpacific transport of Asian anthropogenic aerosols and its impact on surface air quality in the United States, J. Geophys. Res., 111, D14310, doi:10.1029/2005JD006847.

Hemispheric Transport of Air Pollution (HTAP) (2010), Hemispheric Transport of Air Pollution 2010. Part A: Ozone and Particulate Matter, Air Pollution Studies No. 17, edited by Frank Dentener, Terry Keating, and Hajime Akimoto, United Nations, New York.

Henze, D. K., D. T. Shindell, F. Akhtar, R. J. D. Spurr, R. W. Pinder, D Loughlin, M. Kopacz, K. Singh, and C. Shim (2012), Spatially refined aerosol direct radaitive forcing efficiencies, Environ. Sci. Technol., 46 9511-9518.

Hess, M., P. Koepke, and I. Schult (1998), Optical properties of aerosols and clouds: The software package OPAC, Bull. Am. Meteor. Soc., 79, 831-844.

Huang, M., et al. (2012), Sectoral and geographical contributions to summertime continental United States (CONUS) black carbon spatial distributions, Atmos. Environ., 51, 165-174.

Jacobson, M. Z. (2001), Strong radiative heating due to the mixing state of black carbon in atmospheric aerosols, Nature, 409, 695-697.

Kaufman, Y. J., O. Boucher, D. Tanre, M. Chin, L. A. Remer, and T. Takemura (2005), Aerosol anthropogenic component estimated from satellite data Geophys. Res. Lett., 32, L17804, doi:10.1029/2005GL023125.

Kinne, S., et al. (2006), An AeroCom initial assessment - optical properties in aerosol component modules of global models, Atmos. Chem. Phys., 6 , 1815-1834, doi:10.5194/acp-6-1815-2006.

Koch, D., G. A. Schmidt, and C. Field (2005), Sulfur, sea salt and radionuclide aerosols in GISS, ModelE, J. Geophys. Res., 111, D06206, doi:10.1029/2004JD005550.

Koch, D., T. C. Bond, D. G. Streets, N. Unger, and G. R. van der Werf (2007), Global impacts of aerosols from particular source regions and sectors, J. Geophys. Res., 112, D02205, doi:10.1029/2005JD007024.

Koffi, B., et al. (2012), Application of the CALIOP layer product to evaluate the vertical distribution of aerosols estimated by global models: AeroCom phase I results, J. Geophys. Res., 117, D10201, doi:10.1029/2011JD016858.

Leibensperger, E. M., et al. (2012a), Climatic effects of 1950-2050 changes in US anthropogeic aerosols. Part 1: Aerosol trends and radiative forcing, Atmos. Chem. Phys., 12, 3333-3348.

Leibensperger, E. M., et al. (2012b), Climatic effects of 1950-2050 changes in US anthropogenic aerosols. Part 2: Climate response. Atmos. Chem. Phys., 12, 3349-3362.

Levy, H., M. Schwarzkopf, L. Horowitz, V. Ramaswamy, and K. Findel (2008), Strong sensitivity of late 21 st century climate to projected changes in short-lived air pollutants. J. Geophys. Res., 113, D06102, doi:10.1029/2007JD009176.

Li, Z., K.-H. Lee, Y. Wang, J. Xin, and W.-M. Hao (2010), First observation-based estimates of cloud-free aerosol radiative forcing across China, J. Geophys. Res., 115, D00K18, doi:10.1029/2009JD013306.

McCormick, R. A., and J. H. Ludwig (1967), Climate modification by atmospheric aerosols, Science, 156, 1358-1359.

Myhre, G., et al. (2012), Radiative forcing of the direct aerosol effect from AeroCom Phase II simulations, Atmos. Chem. Phys. Discuss., 12, 22,355-22,413, doi:10.5194/acpd-12-22355-2012.

Pfister, G. G., P. G. Hess, L. K. Emmons, P. J. Rasch, and F. M. Vitt (2008), Impact of the summer 2004 Alaska files on top of the atmosphere clear-sky radiation fluxes, J. Geophys. Res., 113, D02204, doi:10.1029/2007JD008797.

Pozzoli, L, I. Bey, S. Rast, M. G. Schultz, P. Stier, and J. Feichter (2008a), Trace gas and aerosol interactions in the fully coupled model of aerosolchemistry-climate ECHAM5-HAMMOZ: 1. Model description and insights from the spring 2001 TRACE-P experiment, J. Geophys. Res., 113, D07308, doi:10.1029/2007/JD009007

Pozzoli, L, I. Bey, S. Rast, M. G. Schultz, P. Stier, and J. Feichter (2008b) Trace gas and aerosol interactions in the fully coupled model of aerosolchemistry-climate ECHAM5-HAMMOZ: 2. Impact of heterogeneous chemistry on the global aerosol distribution, J. Geophys. Res., 113, D07309, doi:10.1029/2007/JD009008.

Prospero, J. M., D. L. Savoie, and R. Arimoto (2003), Long-term record of nss-sulfate and nitrate in aerosols on Midway Island, 1981-2000: Evidence of increased (now decreasing?) anthropogenic emissions from Asia, J. Geophys. Res., 108, 4019, doi:10.1029/2001JD001524.

Prospero, J. M., W. M. Landing, and M. Schulz (2010), African dust deposition to Florida: Temporal and spatial variability and comparisons to models, J. Geophys. Res., 115, D13304, doi:10.1029/2009jd012773.

Ramanathan, V., et al. (2001), Indian Ocean Experiment: An integrated analysis of the climate forcing and effects of the great IndoAsian haze, J. Geophys. Res., 106, 28,371-28,398, doi:10.1029/ 2001JD900133.

Ramanathan, V., et al. (2007), Atmospheric brown clouds: Hemispherica and regional variations in long-range transport, absorption, and radiative forcing, J. Geophys. Res., 112, D22S21, doi:10.1029/2006JD008124.
Reddy, M. S., and O. Boucher (2007), Climate impacts of black carbon emitted from energy consumption in the world's regions. Geophys. Res. Lett., 34, L11802, doi:10.1029/2006GL028904.

Rotman, D. A., et al. (2004), IMPACT, the LLNL 3-D global atmospheric chemical transport model for the combined troposphere and stratosphere: Model description and analysis of ozone and other trace gases, J. Geophys. Res., 109, D04303, doi:10.1029/2002JD003155.

Rudich, Y., Y. J. Kaufman, U. Dayan, H. Yu, and R. G. Kleidman (2008), Estimation of transboundary transport of pollution aerosols by remote sensing in the eastern Mediterranean, J. Geophys. Res., 113, D14S13, doi:10.1029/2007JD009601

Samset, B. H., and G. Myhre (2011), Vertical dependence of black carbon, sulfate and biomass burning aerosol radiative forcing, Geophys. Res. Lett., 38, L24802, doi:10.1029/2011GL049697.

Satheesh, S. K., and V. Ramanathan (2000), Large differences in tropical aerosol forcing at the top of atmosphere and Earth's surface, Nature, $405,60-63$.

Schulz, M., et al. (2006), Radiative forcing by aerosols as derived from the AeroCom present-day and pre-industrial simulations, Atmos. Chem. Phys., 6, 5225-5246, doi:10.5194/acp-6-5225-2006.

Shindell, D. T., et al. (2006), Simulations of preindustrial, present-day, and 2100 conditions in the NASA GISS composition and climate model G-PUCCINI, Atmos. Chem. Phys., 6, 4427-4459, doi:10.5194/acp-6-4427-2006.

Shindell, D., et al. (2008a), Climate forcing and air quality change due to regional emissions reductions by economic sector, Atmos. Chem. Phys., 8, 7101-7113

Shindell, D., et al. (2008b), Multimodel projections of climate change from short-lived emissions due to human activities. J. Geophys. Res., 113, D11109, doi:10.1029/2007JD009152.

Shindell, D., et al. (2008c), A multi-model assessment of pollution transport to the Arctic. Atmos. Chem. Phys., 8, 5353-5372.

Shindell, D., M. Schulz, Y. Ming, T. Takemura, G. Faluvegi, and V. Ramaswamy (2010), Spatial scales of climate response to inhomogeneous radiative forcing. J. Geophys. Res., 115, D19110, doi:10.1029/2010JD014108.

Shindell, D. T., A. Voulgarakis, G. Faluvegi, and G. Milly (2012), Precipitation response to regional radiative forcing. Atmos. Chem. Phys., 12, 6969-6982.

Stier, P., et al. (2012). Host model uncertainties in aerosol radiative forcing estimates: results from the AeroCom prescribed intercomparison study, Atmos. Chem. Phys. Discuss., 12, 25,487-25,549, doi:10.5194/acpd-1225487-2012.

Takemura, T., T. Nozawa, S. Emori, T. Y. Nakajima, and T. Nakajima (2005), Simulation of climate response to aerosol direct and indirect effects with aerosol transport-radiation model. J. Geophys. Res., 110, D02202, doi:10.1029/2004JD005029.

Tang, I. N. (1996), Chemical and size effects of hygroscopic aerosols on light scattering coefficient, J. Geophys. Res., 101, 19,245-19,250, doi:10.1029/96JD03003

Textor, C., et al. (2006), Analysis and quantification of the diversities of aerosol life cycles within AeroCom, Atmos. Chem. Phys., 6, 1777-1813, doi:10.5194/acp-6-1777-2006.

Textor, C., et al. (2007), The effect of harmonized emissions on aerosol properties in global models - an AeroCom experiment, Atmos. Chem. Phys., 7, 4489-4501.

Torres, O., H. Jethva, and P. K. Bhartia (2012), Retrieval of aerosol optical depth over clouds from OMI observations: Sensitivity analysis and case studies, J. Atmos. Sci., 69, 1037-1053, doi:10.1175/JAS-D-11-0130.1.

Twomey, S. (1977), The influence of pollution on the shortwave albedo of clouds, J. Atmos. Sci., 34, 1149-1152.

U.S. Climate Change Science Program. (2009), Atmospheric aerosol properties and climate impacts, a report by the U.S. Climate Change Science Program and the Subcommittee on Global Change Research, edited by Mian Chin, Ralph A. Kahn, and Stephen E. Schwartz, 128 pp., National Aeronautics and Space Administration, Washington, D. C.

VanCuren, R. A. (2003), Asian aerosols in North America: Extracting the chemical composition and mass concentration of the Asian continental aerosol plume from long-term aerosol records in the western United States, J. Geophys. Res., 108, 4623, doi:10.1029/2003JD003459.

Wang, J., D. J. Jacob, and S. T. Martin (2008), Sensitivity of sulfate direct climate forcing to the hysteresis of particle phase transitions, J. Geophys. Res., 113, D11207, doi:10.1029/2007JD009368.

Waquet, F., J. Riedi, C. Labonnote, P. Goloub, B. Cairns, J.-L. Deuze, and D. Tanre (2009), Aerosol remote sensing over clouds using A-Train observations, J. Atmos. Sci., 66, 2468-2480.

$\mathrm{Yu}, \mathrm{H}$, et al. (2004), The direct radiative effect of aerosols as determined from a combination of MODIS retrievals and GOCART simulations, $J$. Geophys. Res., 109, D03206, doi:10.1029/2003JD003914.

$\mathrm{Yu}, \mathrm{H}$, et al. (2006), A review of measurement-based assessments of the aerosol direct radiative effect and forcing, Atmos. Chem. Phys., 6, 613-666, doi:10.5194/acp-6-613-2006. 


\section{YU ET AL.: AEROSOL INTERCONTINENTAL TRANSPORT}

Yu, H., L. A. Remer, M. Chin, H. Bian, R. G. Kleidman, and T. Diehl (2008), A satellite-based assessment of transpacific transport of pollution aerosol, J. Geophys. Res., 113, D14S12, doi:10.1029/ 2007JD009349.

$\mathrm{Yu}$, H., M. Chin, L. A. Remer, R. G. Kleidman, N. Bellouin, H. Bian, and T. Diehl (2009), Variability of marine aerosol fine-mode fraction and estimates of anthropogenic aerosol component over cloud-free oceans from the Moderate resolution Imaging Spectroradiometer (MODIS), J. Geophys. Res., 114, D10206, doi:10.1029/2008JD010648.

$\mathrm{Yu}$, H., L.A. Remer, M. Chin, H. Bian, Q. Tan, T. Yuan, and Y. Zhang (2012a), Aerosols from overseas rival domestic emissions over North America, Science, 337, 566-569, doi:10.1126/science.1217576.
Yu, H., Y. Zhang, M. Chin, Z. Liu, A. Omar, L. A. Remer, Y. Yang, T. Yuan, and J. Zhang (2012b), An integrated analysis of aerosol above clouds from A-Train multi-sensor measurements, Remote Sens. Environ., 121, 125-131, doi:10.1016/j.rse.2012.01.011.

Yu, H., L. A. Remer, R. A. Kahn, M. Chin, and Y. Zhang (2013), Satellite perspective of aerosol intercontinental transport: From qualitative tracking to quantitative characterization, Atmos. Res., doi:10.1016/j. atmosres.2012.12.013, in press.

Zhou, M., H. Yu, R. E. Dickinson, O. Dubovik, and B. N. Holben (2005), A normalized description of the direct effect of key aerosol types on solar radiation as estimated from AERONET aerosols and MODIS albedos. J. Geophys. Res., 110, D19202, doi:10.1029/2005JD005909. 